IZA DP No. 6754

Constitutions and Economic Development: Evidence from the American Indian Nations

Randall Akee

Miriam Jorgensen

Uwe Sunde

July 2012 


\title{
Constitutions and Economic Development: Evidence from the American Indian Nations
}

\author{
Randall Akee \\ Tufts University \\ and IZA \\ Miriam Jorgensen \\ University of Arizona \\ Uwe Sunde \\ University of St. Gallen, SEW-HSG, \\ IZA and CEPR \\ Discussion Paper No. 6754 \\ July 2012 \\ IZA \\ P.O. Box 7240 \\ 53072 Bonn \\ Germany \\ Phone: +49-228-3894-0 \\ Fax: +49-228-3894-180 \\ E-mail: iza@iza.org
}

\begin{abstract}
Any opinions expressed here are those of the author(s) and not those of IZA. Research published in this series may include views on policy, but the institute itself takes no institutional policy positions.

The Institute for the Study of Labor (IZA) in Bonn is a local and virtual international research center and a place of communication between science, politics and business. IZA is an independent nonprofit organization supported by Deutsche Post Foundation. The center is associated with the University of Bonn and offers a stimulating research environment through its international network, workshops and conferences, data service, project support, research visits and doctoral program. IZA engages in (i) original and internationally competitive research in all fields of labor economics, (ii) development of policy concepts, and (iii) dissemination of research results and concepts to the interested public.
\end{abstract}

IZA Discussion Papers often represent preliminary work and are circulated to encourage discussion. Citation of such a paper should account for its provisional character. A revised version may be available directly from the author. 


\section{ABSTRACT}

\section{Constitutions and Economic Development: Evidence from the American Indian Nations}

This paper presents an empirical examination of economic and institutional development. Utilizing a novel data set on American Indian tribal nations, we investigate how constitutional design affects economic development, while holding the broader legal and political environment fixed. Instrumental variables regressions, using the party of the US President at the time of the initial adoption of tribal constitutions as an instrument for constitutional design, indicate that parliamentary systems (versus presidential) have a strong positive effect on economic development, while ordinary least squares regressions of current economic outcomes on parliamentary systems of government show no effects. Robustness checks suggest that the results are not explained by differences in other institutions or geographic characteristics. Additional results provide some suggestive evidence that the effects may operate through channels that are typically associated with parliamentary systems, such as larger public employment, and more equitable income distribution.

JEL Classification: D72, N12, O11, O43, P16

Keywords: economic development, constitutional design, political economy

Corresponding author:

Randall Akee

Tufts University

Department of Economics

8 Upper Campus Road, Braker 114B

Medford, MA 02155

USA

E-mail: randall.akee@tufts.edu

\footnotetext{
* We acknowledge Tufts University Faculty Research Awards Committee Funding (October 2009) which provided funding for data collection on this project and the Center for Labor Economics, UC Berkeley. We would like to thank Mevlude Akbulut-Yuksel, Jenny Aker, Ernesto Dal Bo, Lukas Buchheim, Carl-Johan Dalgaard, Rajeev Dehejia, Bruce Duthu, Lakshmi lyer, Joseph Kalt, Peter Kuhn, Emilia Simeonova, James Snyder, Enrico Spolaore, Rudi Stracke, Lowell Taylor, Thomas Vischer, Romain Wacziarg, Mutlu Yuksel, Jeffrey Zabel and Larissa Zierow for helpful comments and discussions as well as seminar participants at the University of Southern California, UC Santa Cruz, the College of Willilam and Mary, Lewis and Clark Law School and PERC Workshop, University of Hawaii, and the Center for Global Development. We would like to thank Rezwan Khan, Jarrod Smith, Mark Adams, Jaehee Choi and Conor Carney for excellent research assistance. Additionally, David Selden and James Bryant at the National Indian Law Library were incredibly helpful in providing access to materials invaluable for this research. Any errors, omissions or oversights are our own.
} 


\section{Introduction}

The importance of political institutions for economic development is one of the most intensely researched areas in economics and political science of the recent years. A particularly intense debate concerns the causal effect of constitutional design on economic performance. Are the features of constitutions, such as the form of state, a relevant determinant of economic development? And how severe is reverse causality from economic development to the design of constitutions?

This paper contributes to this literature by providing novel evidence for the effects of particular aspects of constitutional design, namely the form of state in terms of the accountability of the executive to the electorate, on economic performance. By isolating the causal effects of constitutions on economic performance, we also provide indirect evidence for the reverse channel of causality in terms of endogenous adoption of particular constitutions. The analysis is based on a newly assembled data set of American Indian tribal constitutions for 70 American Indian tribes with democratic governments and written constitutions. We have coded the information contained in these documents such as whether the executive is directly elected or indirectly elected as well as the year of the adoption of the first modern constitution and the years in which amendments occurred. All of these documents span the entirety of the 20th century. We merge this data with information on economic development indicators for the American Indian tribes in 1900, 1990, and 2005-2009 from the US Census and investigate the effect of political institutions on economic performance.

The structure of the data resembles the typical structure of the empirical work on the long-run effects of institutions, but has important additional features. First, since American Indian Nations are subject to the same broader institutional framework of the United States, the data provide the unique possibility of holding the broader legal and political environment fixed. This alleviates many of the issues that affect the cross-country panel data common in this literature. Second, while the broader legal and political environments are held constant within the US federal framework, these American Indian Nations exhibit substantial heterogeneity in constitutional features. Third, the data contain an element of exogenous variation that can be exploited for identification purposes since, for some tribes, the choice of the constitutional details was heavily influenced by the US Federal government. These constitutional details were determined without regard to the economic conditions in the particular tribes at the time of constitutional adoption. We propose the use of the party of the US President at the time of adoption of the American Indian constitution as a plausible instrumental variable. This instrument is unrelated to future economic outcomes but is directly related to the types of political institutions initially adopted; the executive branch of the US Federal government historically had a large amount of influence over American Indian constitutions. In later sections of this paper, we describe at length the rationale for this instrument and discuss why the instrument plausibly satisfies the exclusion restriction. We are thus able to replicate the typical identification strategy in the literature, and estimate the effects of constitutional design (and political institutions) on economic performance of American Indian 
Nations in modern times.

Our results suggest that there is indeed a bi-directional causal relationship between constitutional details and economic performance when comparing the results from OLS regressions and from IV estimates that exploit exogenous variation in constitutional details. In OLS regressions, we find no effects of political institutions on economic development between 1990 and 2005-2009. These results are likely to be subject to endogeneity bias, however. Results from instrumental variables estimations indicate that political institutions do affect economic growth. In particular, tribes with indirectly elected chief executives (i.e., a parliamentary form of government) have significantly faster growth in per capita incomes, labor force participation rates, and college education, as well as significantly lower unemployment growth over the 1990 to 2005-2009 period.

Additional results demonstrate the robustness of our findings and provide evidence for the channels through which the effects work. The results are robust to additional controls for economic development such as the year of the adoption of the initial constitution, the distance to the nearest city, and regional controls. We also find that the existence of other political institutions, such as having an independent judiciary, staggered elections, or the size of the tribal council do not affect our results. Finally, accounting for the presence of casino operations on the tribal reservations does not reduce the size of the coefficient on an indirectly elected chief executive. Placebo estimates suggest that the results are not driven by a non-random selection of tribes as tribes do not differ in observable characteristics prior to the adoption of the first constitution.

The form of state is a central constitutional feature that affects economic development through several channels. Parliamentary systems are likely to exhibit larger government expenditures, more employment in the public sector, as well as higher degrees of redistribution, but also a larger potential for nepotism, inefficient use of public resources, and corruption (see, e.g., Persson, Roland and Tabellini, 1997, or Alt and Lassen, 2007). As potential channels for the effect of constitutional design, we investigate the role of governmental employment and redistribution. In line with the predictions from the political economy literature, we find evidence that tribes with a parliamentary form of government exhibit larger states in terms of employment in the public sector. We also find evidence for a reduction in poverty in addition to the effect on mean incomes, consistent with the prediction of more redistribution and equality in parliamentary systems. These results suggest that the observed economic improvements are driven by increased government employment and business opportunities for tribal governments with initial parliamentary institutions.

Our paper contributes to the literature on the effects of political institutions for public policies and economic development. Persson and Tabellini (2003, 2004) estimated the effect of different forms of state and electoral rules on central government expenditures, redistribution, and debt using cross-country panel data and find lower levels of central government expenditures and redistribution in presidential systems. While these findings have been criticized with regards to the potential endogeneity of constitutions to economic performance (Acemoglu 2005), Persson and Tabellini (2006) found evidence for the form of government affecting the economic performance of newly democratized countries using panel regressions. More recently, Coate and 
Knight (2011) investigate the effect of government form on public spending at the community level and find evidence that public spending is lower in governments with directly elected executive (mayor-council form of government) than under indirectly elected (council-manager) governments. Their theoretical results also suggest, however, that depending on the preferences distribution either system can be preferable to the electorate. Rather than looking at fiscal policy outcomes as these works, our study focuses on development outcomes. More importantly, our data allows us to rule out potential endogeneity and estimate the causal effect of constitutional design on development by applying an identification strategy based on the random assignment of constitutional design through the influence of the US Federal government.

Our investigation complements earlier studies on the effects of institutions on development, including studies by Acemoglu, Johnson, and Robinson (2001), Iyer (2011), or Acemoglu et al. (2012). In contrast to these studies, we observe the institutions at their initial adoption as well as contemporaneously. This study also contributes to another important strand of the literature that focuses on the determinants of political institutions, and the persistence of institutions over time, pioneered by Acemoglu and Robinson (2000, 2001, 2006). This literature suggests that political institutions are shaped by self-interests of different groups of society as well as by constraints on the possibility of political rulers to commit to certain policies. Institutions emerge endogenously and do not necessarily reflect the institutional design that would lead to efficient economic outcomes, but rather reflect distributional conflicts and inequality in de facto political power. The case of American Indian Nations provides a suitable laboratory to study the effects of institutions on development because of the availability of exogenous influences that shape the initial constitutional design and that can be exploited to shed new light on the causal role of institutions for development, as well as on potential endogeneity in constitutional design. Our paper also adds to the growing literature on the effect of political institutions on economic development and the provision of public goods in developing countries. There is evidence that increases in electoral accountability significantly reduces politician corruption. In Brazil, Ferraz and Finan $(2008,2009)$ find that electoral rules which increase accountability (the possibility of re-election) results in reduced corrupt behavior. They also find that voters respond to evidence (published audit reports of mayoral budgets) about politician behavior and punish more corrupt incumbents at election time. Finally, our paper also adds to a small, but important, literature on the effect of contemporaneous constitutional characteristics on economic development for American Indians. We contribute to the literature pioneered by Cornell and Kalt (1995a, 1995b, 2000) by adding information of the initial types of constitutions adopted and their implications for subsequent development.

The remainder of the paper proceeds as follows. The next section provides some background information on American Indian Tribal nations and discusses the data and sample construction. Section 3 presents the empirical strategy, and Section 4 presents the main empirical results, the results from robustness checks, and additional results regarding the channel through which the effect operates. Section 5 concludes. 


\section{Data on Constitutions of American Indian Nations}

\subsection{Historical Background}

American Indian Nations are a third form of government recognized in the US Constitution along with the US Federal and State governments (Duthu, 2008). Indeed, the US Constitution treated many of the American Indian Nations as foreign nations at least at the time of the establishment of the United States. Over the past two centuries, the US Supreme Court has ruled that American Indian nations are a separate form of government from that of US states, but they have been put under the US federal government's authority and are now classified as "domestic dependent nations" (Wilkins, 2002). Today there are over 560 federally recognized American Indian tribal nations including Alaska Natives. These nations have a direct government-to-government relationship with the United States. There are numerous non-federally recognized tribal governments, but we do not consider these tribal governments in our current analysis.

By 1871, the US unilaterally ceased making treaties with American Indian nations (Duthu, 2008). This marks a turning point in the US relationship with American Indian tribes; the tribes were treated as domestic entities and not the foreign, independent entities of the past. These changes were driven in part by the settlement of much of the continental United States as well as the increased military power of the US. In 1887, the General Allotment Act was created to privatize and develop American Indian lands. The purpose was to transform the American Indians into farmers and small business owners with access to private property and capital. Previously, the American Indian land had been held communally by the entire tribe and was inalienable as well as tax-exempt given the sovereign status of American Indian tribes. The land privatization was a complete failure and reduced the amount of land under American Indian control in 1887 from approximately 138 million acres to about 48 million acres in the early 20th century through coerced land sales, foreclosures and delinquent tax payments (Newton et al, 2005). No corresponding improvement in economic or social conditions for the American Indian land owners was visible; in fact, Hacker and Haines (2005) have shown that child mortality increased significantly for households that received allotted lands. Additionally, the US Supreme Court ruled in the 1903 court case Lone Wolf v. Hitchcock that the US Congress has plenary power over American Indian lands (Duthu, 2008). While the US Constitution discusses American Indian tribes in two places, neither grants Congress plenary power over the tribes (Deloria and Wilkins, 1999). This new Supreme Court interpretation allowed Congress to unilaterally suspend any and all treaty promises without review or redress by American Indian tribes.

American Indians are US citizens and may also be tribal citizens of federally or non-federally recognized tribes (Wilkins, 2006). Federal income tax laws apply to individuals residing on the reservation, but the tribal government itself may be exempt from state and other local jurisdictional laws and taxation (Wilkins, 2002; p. 14). The American Indian nation itself has sovereign immunity and has the ability to establish its own taxation and laws that are not expressly forbidden by the US Congress. This relationship between the US 
government and American Indian tribal nations is based on historical treaties and political relationships during the age of expansion and westward settlement in the US. Preceding the establishment of the US constitution, several American Indian nations had clearly established constitutions and rules of governance, for example the so-called Five Civilized Tribes (Deloria \& Lytle, 1983). In this work, we examine the promulgation and adoption of modern constitutions in American Indian nations after the age of US westward expansion and the establishment of reservation based American Indian Nations at the beginning of the 20th century.

Overall the history of American Indians in the United States has been one of poverty and substantial underdevelopment. Lands under American Indian control in the continental United States amounts to approximately fifty six million acres or about 4 percent of all US lands (Wilkins, 2002). Recently there has been some improvement in economic conditions; real per capita income has increased by 33\% between 1990 and 2000 for American Indians residing on reservations. Additionally, family poverty rates have fallen about 10 percentage points between 1990 and 2000 (48\% to $37 \%$ for tribes without casino operations and $36 \%$ to $27 \%$ for tribes with casino operations), see Kalt and Taylor (2005). Our research aims to investigate the political determinants of these improvements in economic outcomes.

\subsection{American Indian Constitutions}

The history of American Indian constitutional change provides a very interesting case for studying the impact of political institutions on economic development. The composition and nature of the initial constitutions adopted by most American Indian tribes was not necessarily of their own doing. The Bureau of Indian Affairs played a very important role in the design of many of these tribal constitutions. Templates of the important clauses and sections of constitutions were distributed to tribes via the Bureau of Indian Affairs (Wilkins, 2006; Cohen, 2006). The starting point of most American Indian tribal constitutions was not from pre-existing governance systems, but a US-inspired version. These imposed, and to the American Indian nations somewhat foreign, political institutions did not necessarily reflect traditional or moral tribal values and led to high levels of political turmoil and corruption in tribal government activities (Cornell and Kalt, 2000). Due to the perceived illegitimacy of some of these government types, tribal governments have faced a range of problems such as political instability, government closure and attacks on government officials (Lemont, 2006; p 3). While a few American Indian tribes had constitutions in the 1800's, many of these tribes were forcefully relocated by the US Federal government and resulted in a disruption of these pre-existing governments (Wilkins, 2002). Consequently, new constitutions were adopted in the early 20th century to reflect the new geographic, political and economic conditions for these American Indian tribal nations. Several changes occurred at the end of the 19th and beginning of the 20th centuries with regard to the US Federal government's relationship and dealings with American Indian tribes. After the conclusion of the US Civil War, the US Federal government moved the Bureau of Indian Affairs from the War Department to the new Department of the Interior signaling a change in the threat level associated with American Indian tribes (Wilkins, 2002). 


\subsection{Data Sources}

For this study, we collected American Indian constitutions and their amendments for over 70 American Indian nations. The empirical analysis is based on American Indian governments that have democratic forms of government, a written constitution, and a population of more than 750 citizens. One criterion for selecting these American Indian nations was that they had to have a sufficiently large population for political engagement. There are over 560 federally recognized American Indian and Alaska Native nations in the US. A large proportion of the federally recognized tribes have tribal populations that number only a few hundred people. Therefore, we restricted our analysis to the large tribes with at least 750 members. The smaller tribal nations were omitted for several reasons. The first is that generally the smaller tribes have less resources and operate on a more informal basis; family and clan relationships tend to dominate in these particular tribes. Second, many of these smaller tribes do not have a formal, written constitution. In fact, in the current analysis we omit all tribes with unwritten legal and political codes. This necessarily eliminates tribes such as the Navajo Nation which operate on an unwritten, traditional code of governance. We have also omitted the theocracies and corporate governance structures ${ }^{1}$

We compiled the constitutional documents from publicly available sources and locations. The National Indian Law Library, which is part of the Native American Rights Fund, has an extensive collection of constitutions online. Additionally, the University of Oklahoma law library also provides a large collection of American Indian constitutions. We found amendments to the constitutions by direct contact with the tribes, their websites and various inter-library loans from individual law libraries across the country. Finally, we examined constitutions at the Bureau of Indian Affairs in Washington, DC where a number (but not all) of the constitutions are archived.

In total, the data are based on approximately 450 different files or documentation regarding the constitution or the amendments. We coded the initial political institutions contained in the constitutions and recorded the changes made to these constitutions as well as the year in which they were made. For the purpose of the present study we focus on a central element of the tribal nation's political institution - whether the chief executive is elected indirectly or directly. The data also contain information about other political institutions such as staggered terms and an independent judiciary.

We merge the constitutions and amendment data with census data from the 1900 US Census at the tribal government level. This data is available from the Minnesota Population Center IPUMS website and represents a $20 \%$ sample of American Indians by the US Census Bureau. The data contains characteristics of the reservations prior to the adoption of their modern constitutions. The variables, while somewhat limited and

\footnotetext{
${ }^{1}$ The theocratic tribal governments, primarily the Pueblo tribes of the US Southwest, were treated differently due to their long-standing government to government relationships with Spain and Mexico, see Spicer (1962). On the other hand, Alaska Native Villages are often quite small and operate under a corporate governance structure as described in the Alaska Native Claims Settlement Act of 1971 .
} 
not perfectly comparable to recent data from the US Census, are nevertheless useful as control variables for the regressions that follow. As outcome variables, we use data from more recent waves of the US Census (1990 and 2005-2009 American Community Survey) 2 In particular, we have selected four variables that reflect economic development on American Indian reservations: per capita income, percent in the labor force, unemployment rate and percent of the population with a post-high school education (tertiary) or more. The variables are indicative of economic conditions on American Indian reservations.

\subsection{Descriptive Statistics}

In Table 1 we present the means and characteristics of our sample data. Panel A of Table 1 provides information on the main outcome variables of interest in our analysis for the year 1990. Average per capita incomein 1990 is approximately $\$ 5,160$ ( in 1990 dollars) which is significantly lower than the US average of $\$ 19,374$ (Kalt and Taylor, 2005). American Indian reservations on average are much less developed than the rest of the United States. For instance, the percentage of adults in the labor force on reservations in 1990 is $57 \%$ and has a minimum amount of just $36 \%$. The unemployment rate is a useful measure of the economic conditions on the reservation. Individual American Indians, of course, have the option to work off of the reservation; we view this as a proxy for economic activity on and around the American Indian reservation. In 1990 the average rate of unemployment was approximately $23 \%$ with ranges as low as $4 \%$ and as high as $44 \%$.

On average, $24 \%$ of adults aged 25 and older on the American Indian reservations have a post-secondary education. We include this measure of human capital in order to identify an additional dimension of economic development on the reservations. There is quite a large range of values across the different tribes with respect to this variable; there is a range of $10-40 \%$ across the reservations in our sample. To account for differences in population size and land area, we also constructed a population density variable from information about the number of people living on Indian lands in 1990 and the square miles of Indian lands in 1990. This logged variable ranges in value from -2.12 to 5.45 with an average log population per square mile of 1.49.

In panel B, the data from the American Community Survey 2005-2009 for American Indian reservations is provided. We have deflated the per capita income to 1990 prices and find that there has been a pronounced increase in real per capita income to $\$ 8,400$. In general, there has been an improvement in all of the four variables as compared to the 1990 levels. Labor force participation has increased, unemployment has decreased and the percent of adults with a post-secondary education has increased on average to $43 \%$.

Panel C of Table 1 provides the variables from the 1900 US Census for the American Indian reservations. While the data for this time period is limited, there are several useful variables that provide some indication of

\footnotetext{
${ }^{2}$ Unfortunately, the US Census Bureau did not collect separate data for American Indian reservations for most of the 20th century; the census geography captures modern reservations starting in the 1990 census. Therefore, we are unable to examine economic outcomes earlier than 1990. Also, the characteristics of the population are now collected annually in the American Community Survey (ACS) and are presented only as 5 year averages for communities with less than 20,000 individuals. Therefore, we use the 2005-2009 ACS data for our current economic outcomes on American Indian reservations.
} 
the levels of economic development on each reservation prior to the adoption of the initial modern constitutions. In 1900 the average age is approximately 26 years; the population is highly skewed towards the young which is characteristic of developing countries. The male-female ratio is roughly equal on average across the different reservations in 1900. Approximately $40 \%$ of the adults on the reservations were married in 1900. The percent of adults in the labor force in 1900 is approximately $20 \%$ on average. The labor force variable does not include self-employed farmers, which may explain this relatively low labor force participation rate. Approximately $17 \%$ of the population of an average reservation is literate in 1900. The literacy variable is a useful proxy for education and general skill levels of the population. Again there is tremendous heterogeneity across tribes with some tribes reporting no literate individuals and other tribes with literacy rates of almost 50\%.

While we do not have a direct measure of individual incomes in the 1900 census $3^{3}$ we do have a measure of occupations. Conveniently, there is an index of occupations which are ranked according to their wages contained in the data. This occupation-income index measure is an imperfect measure of income on the American Indian reservations in 1900 but it is the best available data. We took a simple average of all employed people on the reservation and the mean value is 5.6, the minimum and maximum values are 0 to 13.7 . We view this occupational index measure as an ordinal measure of average income on the reservations.

The 1900 US Census contains an interesting variable which is not present in current census data - the percent of intermarriage between American Indians and non-Indians. While this is a somewhat unusual variable it does provide a proxy measure for the degree of intermixing between the American Indian tribe and the surrounding non-Indian community. Additionally, we view this variable as a measure of social integration across the two groups. While our research is primarily concerned with the effect of political institutions on economic development, this variable allows us to control for potential differences in ethnic heterogeneity across the different American Indian tribes. The average percent of white blood in our sample of reservations is $9 \%$. There is a lot of heterogeneity with certain tribes having no intermixing and a few outliers that have over $40 \%$ white blood in 1900 .

The next set of variables indicate the geographic location of the tribal reservation in five different census regions in the lower US. There are no Eastern American Indian tribes included in this data. As mentioned previously, we have restricted our analysis to the larger, federally recognized American Indian tribes with written constitutions and this necessarily excludes the Eastern tribes.

Panel D of Table 1 provides information about the tribal constitutions and their amendments. The average tribe adopted the first constitution in 1943.4 Around $76 \%$ of tribes adopted their first constitution under a Democratic US Federal administration. At the time of the initial adoption of the constitution, approximately $57 \%$ of the tribes had an indirectly elected chief executive, where the tribal council decides from among its

\footnotetext{
${ }^{3}$ The US Census Bureau began asking individual income information only starting with the 1940 US Census.

${ }^{4}$ Only one tribe adopted the initial constitution after 1990, namely in 1994. Dropping this tribe from the sample does not affect the empirical results.
} 
own members who will be the chief executive. By 1990 that percentage had decreased to $30 \% 5$

\section{Empirical Framework}

This section discusses the identification problem as well as different empirical strategies to identify the effect of political institutions on economic performance.

\subsection{The Estimation Problem}

The goal of this paper is to investigate the potential effect of constitutional design on economic development. The typical framework used in the literature to estimate this effect is given by

$$
Y_{i}=\beta I_{0 i}+\gamma X_{i}+\varepsilon_{0 i}:
$$

where $Y_{i}$ denotes the growth in one of four separate measures of outcomes on reservation $i$ over the time period 1990 to 2005-2009. These outcome variables include per capita income, unemployment level, percent of adults with high school education or more, and percent in the labor force. The vector $X$ includes controls for characteristics of the reservation in 1900, that is, prior to the adoption of the first modern constitutions. In particular, the vector contains the following characteristics of the reservation: average age, share women, marital status, labor force participation rates, measure of intermarriage, occupational-income index measure, and literacy rates. Additionally, $X$ includes controls for reservation characteristics in 1990 such as log per capita income. This accounts for observable differences in economic development as well as for convergence ${ }^{6}$ Institutions $I$ are measured as binary indicators of whether or not the initial constitution of tribe $i$ calls for the chief executive to be indirectly elected $\left(I_{0 i}=1\right)$, where $t=0$ represents the time when the initial constitution is adopted. The indicator is zero $\left(I_{0 i}=0\right)$ when the chief executive is directly elected. In light of the political economy literature, an indirectly elected executive represents a parliamentary system, while a directly elected executive represents a presidential system. Differences in the way the executive is elected reflect differences in the accountability of the executive, and therefore an institutional environment that differs in terms of its conduciveness for economic development (see, also the findings from the cross-country literature, e.g., Persson and Tabellini, 2003, 2004). The coefficient of interest is $\beta$.

\footnotetext{
${ }^{5} \mathrm{An}$ example for a tribe that changed the constitutional details of the election of the executive is the Apache tribe of the Mescalero Reservation in New Mexico. In their first constitution, which was approved on March 25, 1936, the Apaches on the Mescalero Reservation had a business committee elected. The president as well as other functions were then elected by the business committee. These procedures were subsequently reformed, and the new constitution approved on January 12, 1965, stipulated that the tribal president be elected in general elections. Also the organization of government changed along with this reform.

${ }^{6}$ Various combinations of different 1990 control variables do not significantly affect the observed results. Therefore, we use the log per capita income measure as the primary 1990 control variable in our preferred specifcation. See also the robustness results in Section 4.3
} 
In principle, the data also contain information for the constitutions at later points in time. Assuming that $\beta$ is a deep and stable parameter, an alternative estimation could therefore exploit this information at time $t=1$, e.g. in 1990 before our outcomes are measured, and estimate

$$
Y_{i}=\beta I_{1 i}+\gamma X_{i}+\varepsilon_{1 i}
$$

Without additional assumptions, it is not obvious that $\beta$ is actually identified in these estimation frameworks, because reverse causality problems might bias the estimates. For instance, the adoption of a particular constitutional design might be endogenous to the economic development prospects of a particular tribe (such that $I_{0}$ is correlated with $\varepsilon_{0}$ ), or constitutions may change endogenously over time (such that $I_{1}$ might be correlated with $\left.\varepsilon_{1}\right)$.

\subsection{Identification using Initial Assignment of Institutions}

To account for the potential endogeneity problem, we employ an instrumental variables approach that exploits historical conditions in order to identify the effect of constitutional design on economic growth. This is possible due to the peculiarities of the political liberalization process that American Indian tribes underwent in the late 19th and early 20th Century.

US Presidential Party and the Adoption of American Indian Constitutions. As the 19th century drew to a close the political and legal landscape changed dramatically for American Indian tribes. Previous models of informal governance were not effective in dealing with the reduction in land holdings and rights. The US Federal government reduced the standing of tribal nations to domestic-dependent nations and there began an erosion of rights and protections such as the loss of autonomy and treaty rights. In order to deal more effectively with the US Federal government and the US states, American Indian tribes began to establish centralized governments. Tribes adopted their preferred constitution based on very local and specific conditions and experiences.

In order to establish and adopt formal constitutions, many American Indian tribes sought help and assistance from the Bureau of Indian Affairs (BIA). The BIA operates under the Secretary of the Interior and is appointed by the US President. Congress authorizes the budget of the Bureau of Indian Affairs as noted in the US Constitution and supported by numerous US Supreme Court rulings (Duthu, 2008; Deloria and Wilkins, 1999). Specifically, the Bureau of Indian Affairs responded to requests for assistance in drafting constitutions. Elmer (2006) provides an example for the 1930s where the BIA was tasked with responding to requests for drafting constitutions; the Bureau was not empowered to seek out tribes itself. While there may have been no explicit directive, there appears to have been at least indirect influence in terms of political institutions.

Once a constitution was proposed or considered, the Bureau of Indian Affairs exerted influence and pressure on the kinds of political institutions that could be adopted. The instrumental variable for parliamentary versus 
presidential systems is based on the fact that the nature and type of constitution adopted by American Indian nations has been heavily influenced the Bureau of Indian Affairs, which is subordinate to the Secretary of the Interior of the US Federal Government. The approval and influence of constitution-type is therefore related to the political position of the respective US Presidential administration.

First, under Democratic leadership in the Bureau of Indian Affairs, Felix Cohen, in the 1930s, drafted a document for the writing of tribal constitutions with numerous suggestions. This memo provided extensive information on the clauses and contents of a constitution. Additionally, the document provided a model constitution in the appendix. For the purposes of this paper it is useful in that the model only contained a single type of institution for the election of chief executives - an indirectly elected or parliamentary-type system (Cohen, 2006; Wilkins, 2006; Deloria and Lytle, 1983). Beyond this influence, the Bureau of Indian Affairs had approval power over the nature of the American Indian tribal constitutions. The hypothesis motivating our instrumentation strategy is that under Democratic US Presidents there was a systematic tendency to favor the adoption of the parliamentary type chief executive, while under Republican US Presidents there was a tendency to favor the adoption of the direct election of the chief executive, i.e., a presidential form of government. One reason for the difference is that there might be a difference of opinions according to political party on the idea of assimilation and appropriate political institutions. Theodore Roosevelt, a generation earlier and a Republican US President, saw the new American Indian programs such as allotment as a useful tool to dismember American Indian tribes and to transform them into American ideals. The imposition of a presidential system of government was one method of assimilating the American Indian tribes into the US model of governing. On the other hand, the Democrats and their administration paid more attention to the pre-existing social and political structures. Existing political institutions for American Indians resembled a more communal approach to decision-making and power sharing which is closer to a parliamentary type of government (Champagne, 2006).

An Instrumental Variables Approach. In the following, we exploit these peculiarities by using the party of the US President at the time of the American Indian tribes' adoption of their initial constitution as an instrument for the constitutional design. Consequently, our first stage regression when considering initial institutions in terms of $I_{0}$ as in (1) is given by

$$
I_{0 i}=\lambda Z_{i}+\mu X_{i}+u_{0 i}
$$

while the corresponding first stage for an outcome equation with current institutions $I_{1}$, as in (2), is

$$
I_{1 i}=\lambda Z_{i}+\mu X_{i}+u_{1 i}
$$

We use an indicator variable for our instrument, $Z$, that takes the value of 1 if the party of the US 
President at the time of the initial adoption of the American Indian constitution was Democrat and 0 if it was Republican. The outcome variable, $I$, is a binary indicator that takes value 1 if the respective political institution is characterized by indirectly elected executives, and 0 if not. The first stage regression is given by a linear probability model. Provided that for political and ideological reasons Democratic Presidential administrations were more favorable to indirect democratic structures than Republican administrations as was discussed above, the instrument is expected to be positively related to whether the political party of the US President at the time of adoption was a Democrat.7

Constitutional amendments occurred later during 20th century in some tribes when considerable power and authority was restored to American Indian tribes to make decisions about their own political structures. The period, since the mid-1960s onwards is known as the era of Indian Self-Determination. Therefore, we should view these constitutional amendments as being primarily driven by tribal preferences and less influenced by officials from the Bureau of Indian Affairs in this later period. It is an open-question as to what exactly determines these constitutional amendments. There is a clear case to be made for the endogeneity of constitutional changes and economic performance, but uncovering the determinants of these changes ins beyond the scope of this paper.

The maintained assumptions for identification of the effect are that the instrumental variable, $Z$, is not related to the error term in the respective outcome equation (1) or (2) above. There is no evidence that American Indian tribes were making their decisions about whether to adopt a formal constitution based on the political party of the US President or the executive branch appointees. Instead, the historical evidence suggests that the primary motivation for adopting a formal constitution was based on individual reservationbased conditions and was divorced from conditions in Washington, D.C. Additionally, there is no evidence that tribes attempted to game the system and wait for a different US President and a change in political appointees in the executive branch; empirically, there are no large numbers of constitutional adoptions after an election when the party of the US President changes. It is also useful to note that the party of the US President at the time of adoption of the constitution should have no differential (if at all) effect on the funding of American Indian tribal nations in the future; funding for American Indian tribal nations is appropriated by the US Congress and has no relationship to prior US Presidential administrations. In fact, funding for large programs such as education and health care provision are often tied to simple formulas based on population size (see, for instance, United States General Accounting Office, p. 6, 2003).

In Table 2 we compare the tribal characteristics from the 1900 US Census for the tribes that adopted a constitution under a Republican or Democratic US Presidential administration. The numbers suggest that there is little or no difference in American Indian tribes which adopted constitutions under Democratic or Republican

\footnotetext{
${ }^{7}$ We find no evidence for tribes predominantly adopting new constitutions immediately after or immediately before a change in the US President from one party to the other, or presidential elections. For instance, only 2 tribes adopt a constitution within 2 years of the change in political party; dropping these observations do not change our results.
} 
US Presidents. Based on 1900 observable characteristics we do not find that on average there is a statistically significant difference across the two tribal groups. When comparing the means of the 1900 characteristics between the two types of tribes, we find that none of the characteristics are statistically significant. The only variable with a statistically significant difference at the $10 \%$ level is total white blood, suggesting that tribes that have adopted a constitution under a Republican presidential administration tend to have slightly higher levels of white blood in 1900. This difference, while marginally statistically significant, is about 5 percentage points on average and hence not large in absolute terms, such that, for both types of reservations, the population is still fairly homogenous with a high degree of American Indian blood in 1900. Overall, the descriptives show that tribes were very similar in terms of demographic composition and labor force participation. Most importantly, the two types of tribes do not differ along the other economically meaningful variables such as the occupational-income index score, literacy rates and labor force participation rates.

\section{Empirical Results}

This section presents the main results of our empirical investigation of the role of different election rules for the chief executive on changes in economic development variables between 1990 and 2005-2009. We focus on four outcome variables that are available in the US Census data: per capita income, percent in labor force, unemployment rate and percent with post-high school education. We selected these variables as they are useful indicators of economic development in different dimensions on the reservations at the time. Throughout, we estimate linear models and use the characteristics of the tribe in 1900 as explanatory variables reflecting the term $X$. We present results for the different estimation frameworks discussed above: OLS, as well as 2SLS estimates using the party of the US President at the time of their constitutional adoption as the instrument for institutions at constitutional adoption, $I_{0}$, or after subsequent amendments by $1990, I_{1}$.

\subsection{Constitutional Design and Economic Performance: OLS Results}

Table 3 presents the results of OLS regressions of economic development in terms of changes in the economic development variables between 1990 and 2005-2009 as dependent variable on constitutional design variables and controls. Columns (1)-(4) present results for specification (1) with constitutional design when constitutions where adopted, while Columns (5)-(8) present results for the specification (2) with political institutions measured in 1990. The estimated coefficients for constitutional design in terms of indirectly elected executive are small in magnitude and statistically insignificant for all cases. The results suggest that neither initial nor current political institutions have a significant effect on the change in economic development variables. These findings are likely to be biased because of endogeneity problems, however. The bias might arise due to endogeneity in the sense that systematic but unobserved cross-tribal differences determine institutional design as well as economic performance. In addition, the estimates of specification (2) might also be affected by 
endogenous changes in the institutions after the initial adoption of a constitution in response to economic performance ex interim. For instance, the coefficient on directly elected chief executive is likely to be different in specifications (1) and (2) as tribes amend their constitutions in response to political conflicts among the tribe members, or in order to attain better economic performance. This might contribute additional variance that biases the estimates and renders the returns associated with a particular type of political institution statistically insignificant. Taken together, the results from ordinary least squares regressions suggest that political institutions have little effect on changes in economic development between 1990 and 2005-2009.

\subsection{Constitutional Design and Economic Performance: 2SLS Results}

To account for the potential endogeneity bias that affects these estimates, we proceed by presenting results that exploit exogenous variation in constitutional design using our instrumentation approach. The specification of the outcome equation is again as in (1) or (2), respectively, but the effect of institutions $I$ is estimated using the the party of the US President at the time of adoption of the first constitution as instrument.

Table 4 presents reduced form estimates of economic development over the period 1990-2005/9 regressed on the binary instrument of whether the US president was a Democrat at the time of the initial adoption of the respective tribal constitution. The results suggest that tribes that adopted their initial constitution under a Democrat federal administration exhibit significantly faster income growth, as well as a faster increase in labor force participation, a slower increase in unemployment rates and an increase in the percent of adults on the reservation with post-secondary education, compared to tribes that adopted their initial constitutions under a Republican federal administration.

Table 5 presents the results from 2SLS regressions. Column (I.1) contains the first stage estimates of the instrumented variable as in (3) - constitutional design in terms of indirectly elected executive at the time of the initial adoption of the constitution - regressed on the instrument of whether the US President was Democrat at the time of the initial tribal constitution adoption, plus controls. The instrument has a statistically highly significant effect on the constitutional design at initial adoption, indicating that, as expected, tribes that adopted their initial constitution under a Democrat president were more likely to have executives elected indirectly. The F-Statistic for this instrument is 14.79 , indicating that the first stage relation is reasonably strong. Columns (1)-(4) present estimates for outcome equations on the second stage. The results largely confirm the results of the reduced form estimates. Constitutional design has significant effects on economic performance. Tribes with constitutions that stipulate indirectly elected executives have faster income growth over the period 1990-2005/9, exhibit faster growth of the labor force, a faster drop in unemployment, and an increase in people with post-secondary education on the reservation. All these results hold conditional on the level of development in 1990, as proxied by income per capita. The log difference in income per capita is about 0.36 larger for tribes with indirectly elected executives. This is approximately half of the difference in mean income provided in Table 1 between 1990 and 2005-2009, and corresponds to annual growth in income 
per capita being about 2.5 percent faster on average. The labor force grows by about half a percentage point faster each year; and unemployment shrinks by about half a percentage point faster per year. The percent of adults older than 25 that have post-secondary education increases by about $4 \%$ over this time period.

The second part of Table 5 presents the corresponding results when adopting specification (2) and estimating the effects of constitutional details by instrumenting institutions as of 1990, at the beginning of the period in which outcomes are measured, as in (4). In light of the fact that tribes might have changed their constitutions between the initial adoption and 1990, potentially in response to economic performance or for other political economy reasons, it is to be expected that the instrument is weaker in this specification than for constitutions at adoption.

Column (I.2) presents the respective first stage estimates, which confirm this conjecture. The coefficient estimate of the instrument on the first stage is smaller and statistically less significant. Although there is a positive and significant effect of having a Democrat administration for the US President on the probability that a tribe has an indirectly elected chief executive in 1990, the F-Statistic for this instrument is only 6.75. Columns (5)-(8) present results for the outcomes in terms of economic development variables between 1990 and 2005-2009 on the second stage. Throughout, the results confirm the previous results in Columns (1)-(4). Having a constitution stipulating indirectly elected executives in 1990, instrumented by having a Democratic Federal administration at the initial adoption results, has a positive effect on income growth and labor force participation, implies a faster reduction in unemployment, and an increase in post-secondary educated individuals on the reservation. In terms of magnitude, all estimates obtained with specification (2) imply larger effects on the second stage. This could be due to a problem of a weaker performance of the instrument on the first stage. Alternatively, it is possible that current institutions have a stronger effect on outcomes than initial institutions, which might have changed subsequently and hence do not reflect the actual institutional setting at the beginning of the observation period of outcomes. The emerging picture is therefore consistent with initial institutions, $I_{0}$, rather than contemporaneous institutions, $I_{1}$, being more strongly affected by the instrument (having a stronger influence on political institution decisions at the moment of adoption), but having a weaker effect on current outcomes as compared to current institutions.

To conclude, for tribes that comply with the assignment of political institutions at the time of adoption as determined by the party of the US President, we find that those with an indirectly elected chief executive have better economic performance in terms of a larger growth in per capita income, a faster increase in labor force participation, a faster reduction in unemployment and an increase in the percent of adults on the reservation with post-secondary education.

\subsection{Robustness}

This section presents several robustness checks in order to investigate whether other potential mechanisms are responsible for the observed outcomes. The respective tables are found in the Appendix. 


\subsubsection{Years Since Constitutional Adoption and Distance to Nearest Large City}

The results so far were obtained under the premise that the federal administration at the adoption of the initial tribal constitution is a valid instrument for constitutional design in terms of the form of government stipulated by the constitutional article on whether executives are elected directly or indirectly. The validity of this instruments hinges on two critical assumptions. First, the federal administration must not reflect other unobserved heterogeneity in tribal characteristics that are related with outcomes. This could be the case, for example, if there is a time trend in the adoption of a constitution, such that tribes that adopt their first constitution early on are systematically different from tribes that adopt their constitutions later, i.e., if the years since adoption of a constitution affect the efficacy and efficiency of tribal governments. If the timing of the adoption correlates with the party of the US President, this would render the exclusion restriction invalid and the identification flawed. A potential way to account for this confound is to control directly for the time elapsed since the initial adoption of a constitution.

Second, there might be other characteristics that are unrelated to the timing of the adoption, but that have to do with geographic features that are not accounted for by the region controls 8 For instance, the development potential of a tribal community in terms of income, but in particular labor market performance, might be crucially affected by the possibility to commute off of the tribal reservation for work. To account for this possibility, one would have to control for the distance to the nearest city.

Table 6 presents 2SLS estimation results for the specification of the outcome equation as in (1) that include the years since the constitution was initially adopted, as well as the distance to the nearest city (in miles) as additional controls.9 The results are qualitatively unaffected and quantitatively very similar compared to the previous results. Years since initial adoption has a significant effect on the probability of observing an indirectly elected executive in the initial constitution, but the instrument remains strong and significant in predicting constitutional design. In addition, there is no effect of years since initial adoption on any of the outcomes on the second stage. Distance to the nearest city leaves the first stage unaffected.

\subsubsection{Additional Controls for Development as of 1990}

Table 7 presents the results of a similar analysis to the one above, except that the specification includes additional control variables in terms of the levels of the respective outcome variable as of 1990 . These specifications are equivalent to estimates with the level of the respective outcome variable in 2005/9 as the dependent

\footnotetext{
${ }^{8} \mathrm{An}$ additional characteristic of this analysis is that all of the tribes examined here are federally-recognized by the US Federal government and hence are eligible for the exact same types and amounts of federal programs. There is no differential treatment by the US Federal government and the Bureau of Indian Affairs. There are other state-recognized and non-recognized indigenous peoples in the US that are not included in this analysis for the specific reason that they would face very different economic and social opportunities.

${ }^{9}$ In this and the following robustness checks, we restrict attention to specification (1) due to its better first stage performance. All results are qualitatively similar for estimates of specification $(2)$.
} 
variable, and therefore correspond to the usual specification used in empirical studies of the fundamental determinants of development (see, e.g., Spolaore and Wacziarg, 2012). As in the previous Table, columns (1)-(4) contain second stage results for specification (1) for the outcome equation, while columns (5)-(8) contain results for specification (2). The performance of the respective first stages (not shown) is similar to before, with F-statistics in the range between 13 and 14 for the specifications in columns (1)-(4), and smaller values in the range between 5 and 8 for the various first stages for outcomes in columns (5)-(8). The results on the second stage are quite similar for log percapita income and percent in the labor force to those found previously when only the log per capita in 1990 had been included as additional control variable. However, the coefficients in the unemployment and post-secondary education regressions are smaller in magnitude and statistical significance than in the previous tables.

Table 8 shows the results of estimates of specification (1) with an even more extensive set of controls for development in 1990 in all dimensions. In this table we include all of the 1990 level variables simultaneously in each regression model instead of individually as in Table 7. The results again confirm the previous findings. The F-statistic for the first stage in this model is 15.55. We find robust positive effects of indirect elect executives on income and labor force participation in the second stage results. There is also a negative effect on unemployment and on the percent with a high school diploma, but these effects are not statistically significant.

\subsubsection{Different Institutions and Casinos}

A further potential confounder for the results obtained so far is that constitutions might differ along several dimensions other than whether the executive is elected indirectly or directly. Potentially, other institutions contained within the tribal constitutions may be responsible for the observed differences in economic performance, while these additional institutions are themselves highly correlated with whether a tribe has a parliamentary or presidential system of government. In order to account for these potential confounders, we include additional political institutions as right hand side control variables and investigate how this affects the results for the main outcome, changes in log per capita income. Table 9 presents results for second stage estimates using extended specifications with controls for other components of the constitutions. In particular, the estimates account for whether an independent judiciary exists or not, whether elections are staggered, for the length of an election term, whether a council is directly elected or not, and for the size of the tribal council. The results are robust to the inclusion of these additional variables, whereas none of the individual variables attain statistical significance, except for whether the tribal council is directly elected. Even in this particular case, the coefficient on the indirectly elected chief executive remains large in magnitude and statistical significance 10

\footnotetext{
${ }^{10}$ We also attempted to instrument the different alternative types of institutions using the party of the US President at the time of the adoption of the constitution. The instrument is not strong for any of the potential variables such as the existence of a judiciary, term length, whether the council members elections are staggered, and the initial size of the tribal council. Overall, the instrument
} 
An additional explanation for the observed differences in economic performance across the two types of tribes may be the presence of a casino. In fact, one might suspect that the presence of a casino alone is responsible for the improved economic performance. The results in Table 9 suggest that the inclusion of whether a tribe operates a casino or not as a control variable does not significantly affect the main coefficient of interest. This is consistent with the fact that there is a diversity of tribally-owned enterprises on American Indian reservations. Casino operations are important, but they do not account for all of the economic activity on reservations. Overall, the results therefore confirm the earlier findings that the constitutional design in terms of a parliamentary or presidential type of government has a significant effect on economic performance.

\subsubsection{Placebo Effects}

Finally, we conducted a series of placebo instrumental variables regressions, the results of which can be found in Table 10 in the Appendix. In these regressions, we take the initial values of our control variables from the 1900 census as outcome variables. The six outcome variables are log population density per square mile, percent married on the reservation in 1900, percent in the labor force in 1900, average percent non-Indian on reservation in 1900, occupational-income score in 1900 and percent literate in 1900. For each of these variables, the first column instruments for having an indirectly elected chief executive at the time of adoption of the initial constitution. None of the coefficients are statistically significant. The second column for each variable instruments for having an indirectly elected chief executive in their current constitution. Once again none of the coefficients are statistically significant.

\subsection{Predictions from Political Economy: Potential Channels}

The findings presented so far suggest that constitutional design has a robust causal effect on economic development. In particular, constitutions stipulating indirect elections of the executive that resemble parliamentary forms of government appear to have a better economic performance than constitutions with directly elected executives in terms of the growth of average per capita income, labor force participation rates, post-secondary educated individuals and a reduction in unemployment rates on these reservations. These effects are not explained by other characteristics such as years since adoption, distance to the nearest city, or casino operations, nor through other facets of the political institutions (such as the existence of an independent judiciary or staggered terms), nor by a systematic selection of tribes given the results of the placebo estimates. Nevertheless, the results so far leave open through which channels the form of government might operate to affect economic performance.

In this section, we explore several potential mechanisms that may be responsible for the observed differences is only valid for predicting the method of electing the chief executive in the originally adopted constitutions. Empirically, we also note that most of these institutions are added in later years as constitutional amendments and may be endogenous variables themselves. 
in growth rates across the two different types of institutions. The political economy literature makes several predictions about the economic consequences of these different forms of state (see, e.g., Persson and Tabellini, 2000, 2003).

A first assertion is that parliamentary systems tend to have expansionary bureaucracies and larger expenditures. Hence, one immediate candidate for a potential channel is the share of public employment in tribal reservations, given that employment tends to be a primary concern on American Indian reservations. In our particular environment, we find indeed that the expansion of government employment (primarily tribalgovernment as federal employment - Bureau of Indian Affairs employees - had been steadily decreasing over time on reservations) as a likely candidate for explaining the improvement in economic conditions for American Indian populations residing on reservations 11 Table 11 presents results for the change in the share of government employment (as proportion of the adult population on the reservation) over the course of the 1990 to 2005-09 time period as dependent variable. Column (1) presents the results for the second stage of 2SLS estimates when controlling for the employment composition in 1990. The results document that there is growth in government employment over this time period for tribes that were initially assigned parliamentary systems. In fact, there was a dramatic increase in business opportunities and the ability to operate existing government programs such as education and housing services (Wilkins, 2002, p. 89). A similar analysis with respect to employment in the private sector does not reveal an accompanying improvement in business employment. It appears that the observed increase in per capita income and labor force participation between 1990 and 2005-2009 comes primarily from an increase in government employment. For American Indian reservations, this has meant an expansion of tribally-owned businesses.

We assert that this evidence suggests that the primary role for improved economic performance on American Indian reservations in this time period is due to improved employment prospects. Previously, economic opportunities on reservations had been quite sparse. New industries, in addition to casino and gaming operations, have sprung up on many American Indian reservations in the past twenty five years such as mining, energy production, timber, tourism and recreation, agriculture, hunting and fishing tourism, arts and crafts based industries. Our findings, therefore, are consistent with a story where the most effective tribal governments expand their business operations and increase employment among tribal members. Compared to the average tribe with a presidential system, there is more government employment and, ultimately, the rate of growth is higher and more sustained for tribes with an initial parliamentary system.

A second assertion from the literature on comparative political economy is that parliamentary systems tend to have higher redistribution. Due to the lack of direct information about redistribution, we try to investigate this assertion by considering the change in poverty. In particular, we construct a proxy of poverty: the share of all households on reservations with an income below the contemporaneous median household income in the US

\footnotetext{
${ }^{11}$ See U.S. Commission on Civil Rights (2003, page 11, Figure 1.2) which shows the decrease in per capita expenditures for Native Americans by the US Federal government relative to the US population as a whole over the past three decades.
} 
as a whole. The result, shown in column (3) of Table 11, suggests that poverty declined faster in tribes with indirectly elected executives at the time of adoption of their constitutions ${ }^{12}$ This corroborates the impression that incomes went up in the entire distribution, and in particular at or below the median, rather than only on average.

Taken together, the results suggest that the parliamentary system is likely responsible for the observed improvement in economic conditions. In the emerging democracies on tribal lands, with uncertain conditions and preferences and a poorly-developed private business sector, it appears that a parliamentary system increased the government-owned enterprises and was more likely to improve the economic conditions through job creation. The situation on American Indian reservations has generally improved over the course of the past forty years as a result of a reduction in US Federal government control, better economic opportunities in terms of leasing and development of natural resources.

\section{Concluding Remarks}

This research has used a novel panel data set of political institutions of American Indian tribal nations over the 20th century. We examine the effect existing political institutions on economic development for individual American Indian tribal nations. The American Indian context is particularly useful for focusing on political institutions in several respects: the larger legal, political and economic environment is held constant as they are located within the United States. In our analysis, we find that contemporaneous political institutions have no effect on economic performance in an ordinary least squares regression framework. When using an instrumentation strategy for political institutions that exploits the type of federal administration during the adoption of the initial constitutions, we find significant positive causal effects of parliamentary systems on economic performance. These results are robust to the inclusion of geographic and institutional controls, to the inclusion of other potential constitutional features such as the existence of an independent judiciary or staggering the tribal council election terms, as well as to casino operations. Results of placebo exercises do not indicate that there is systematic selection of tribes into particular constitutional types once accounting for the instrumentation using the party of the US federal administration at the time of adoption of the first constitution. The results also suggest differences in policy, in particular in public employment, as a potential channel through which constitutional features affect outcomes.

Overall, our results provide a first analysis of the causal effect of political institutions and accountability on levels of economic development while holding constant a number of other important determinants of economic

\footnotetext{
${ }^{12}$ It is worth noting that the reduction of poverty is not due to a reduction in the overall poverty in the US as a whole, given that poverty levels in the US in terms of the population below the poverty threshold actually went up. Also, very similar results obtain when poverty is measured by the fraction of households with household income below 15,000 USD (deflated to 1990 prices), which indicates a relative as well as absolute reduction in poverty in tribes with indirectly elected executives relative to directly elected executives.
} 
security and legal structure. While our analysis focuses on a very specific set of governments, our findings may have wider implications by suggesting the importance for studying the mechanisms behind the economic effects of constitutional design. 


\section{References}

Acemoglu, D. (2005): “Constitutions, Politics, and Economics: A Review Essay on Persson and Tabellini's The Econonmic Effects of Constitutions," Journal of Economic Literature, 43(4), 1025-1048.

Acemoglu, D., D. Cantoni, S. Johnson, and J. Robinson (2012): "The Consequences of Radical Reform: The French Revolution," American Economic Review, forthcoming.

Acemoglu, D., S. Johnson, and J. Robinson (2001): "The Colonial Origins of Comparative Development: An Empirical Investigation," American Economic Review, 91(5), 1369-1401.

Acemoglu, D., And J. Robinson (2000): "Why Did the West Extend the Franchise? Democracy, Inequality, and Growth in Historical Perspective," Quarterly Journal of Economics, 115(4), 1167-99.

(2001): “A Theory of Political Transitions," American Economic Review, 91(4), 938-63.

(2006): Economic Origins of Dictatorship and Democracy. Cambridge University Press, Cambridge.

Alt, J. E., AND D. D. LASSEn (2008): "Political and Judicial Checks on Corruption: Evidence from American State Governments," Economics and Politics, 20, 33-61.

Champagne, D. (2006): "Remaking Tribal Constitutions: Meeting the Challenges of Tradition, Colonialism, and Globalization," in American Indian Constitutional Reform and the Rebuilding of Native Nations, ed. by E. D. Lemont.

Coate, S., And B. Knight (2011): "Government Form and Public Spending: Theory and Evidence from US Municipalities," American Economic Journal: Economic Policy, 3(3), 82-112.

Cohen, F. S. (2006): On the drafting of tribal constitutions. University of Oklahoma Press, Norman, OK.

Cornell, S. E., and J. P. Kalt (1995a): "Cultural Evoulution and Constitutional Public Choice: Institutional Diversity and Economic Performance on American Indian Reservations," John F. Kennedy School of Government Faculty Research Working Paper Series.

(1995b): "Where Does Economic Development Really Come From? Constitutional Rule Among the Contemporary Sioux and Apache," Economic Inquiry, 33(3), 402-426.

(2000): "Where's the Glue: Institutional Bases of American Indian Economic Development," Journal of Socio-Economics, 29, 443-470.

Deloria, V. J., And C. M. Lytle (1983): American Indians, American Justice. University of Texas Press, Austin, TX. 
Deloria, V. J., And D. E. Wilkins (1999): Tribes, Treaties, and Constitutional Tribulations. University of Texas Press, Austin, TX.

Duthu, N. B. (2008): American Indians and the Law. Penguin, New York, NY.

Elmer, R. (2006): "The Indian Reorganization Act and Indian Self-Government," in American Indian Constitutional Reform and the Rebuilding of Native Nations, ed. by E. D. Lemont.

Ferraz, C., And F. Finan (2008): "Motivating Politicians: The Impacts of Monetary Incentives on Quality and Performance," IZA Discussion Paper, 3411.

(2009): "Electoral Accountability and Corruption: Evidence from the Audits of Local Governments," NBER Working Paper, 14397.

Hacker, D. J., and M. R. Haines (2005): "American Indian Mortality in the Late Nineteenth Century: The Impact of Federal Assimilation Policies on a Vulnerable Population," Annales De Demographie Historique, $2,17-45$.

IyeR, L. (2011): "Direct Versus Indirect Colonial Rule in India: Long-Term Consequences," Review of Economics and Statistics, 92(4), 693-713.

Kalt, J., AND J. TAYLOR (2005): “American Indians on Reservations:A Databook of Socioeconomic Change Between 1990 and 2000 Censuses," Harvard Project on American Indian Economic Development Working Paper.

Lemont, E. D. (2006): American Indian Constitutional Reform and the Rebuilding of Native Nations. University of Texas Press, Austin, TX.

Newton, N. J., And Et AL. (2005): Cohen's Handbook of Federal Indian Law. Lexis Nexis, Mathew Bender, Newark, NJ.

Persson, T., G. Roland, and G. Tabellini (1997): "Separation of Powers and Political Accountability," Quarterly Journal of Economics, 112(2), 310-327.

Persson, T., and G. Tabellini (2000): Political Economics: Explaining Economic Policy. Mit Press, Cambridge, Massachusetts.

(2003): The Economic Effect of Constitutions. MIT Press, Cambridge, Massachusetts.

(2004): "Constitutional Rules and Fiscal Policy Outcomes," American Economic Review, 94(1), $25-45$.

(2006): "Democracy and Development: The Devil in the Details," American Economic Review, 96(2), $319-324$. 
SpICER, E. H. (1962): Cycles of Conquest: The Impact of Spain, Mexico, and the United States on the Indians of the Southwest, 1533-1960. University of Arizona Press, Tucson.

Spolaore, E., and R. Wacziarg (2012): "How Deep are the Roots of Economic Development," NBER Working Paper, 18130.

United States General Accounting Office (2003): "Bureau of Indian Affairs Schools: Expenditures in Selected Schools Are Comparable to Similar Public Schools, but Data Are Insufficient to Judge Adequacy of Funding and Formulas," Report to Congressional Committees, GAO-03-955.

U.S. Commission on Civil Rights (2003): A Quiet Crisis: Federal Funding and Unmet Needs in Indian Country.

Wilkins, D. E. (2002): American Indian Politics and the American Political System. Rowman \& Littlefield Publishers, New York, NY.

(2006): "Seasons of Change: Of Reforms, Melees, and Revolutions in Indian Country," . 
Table 1: Descriptive Statistics

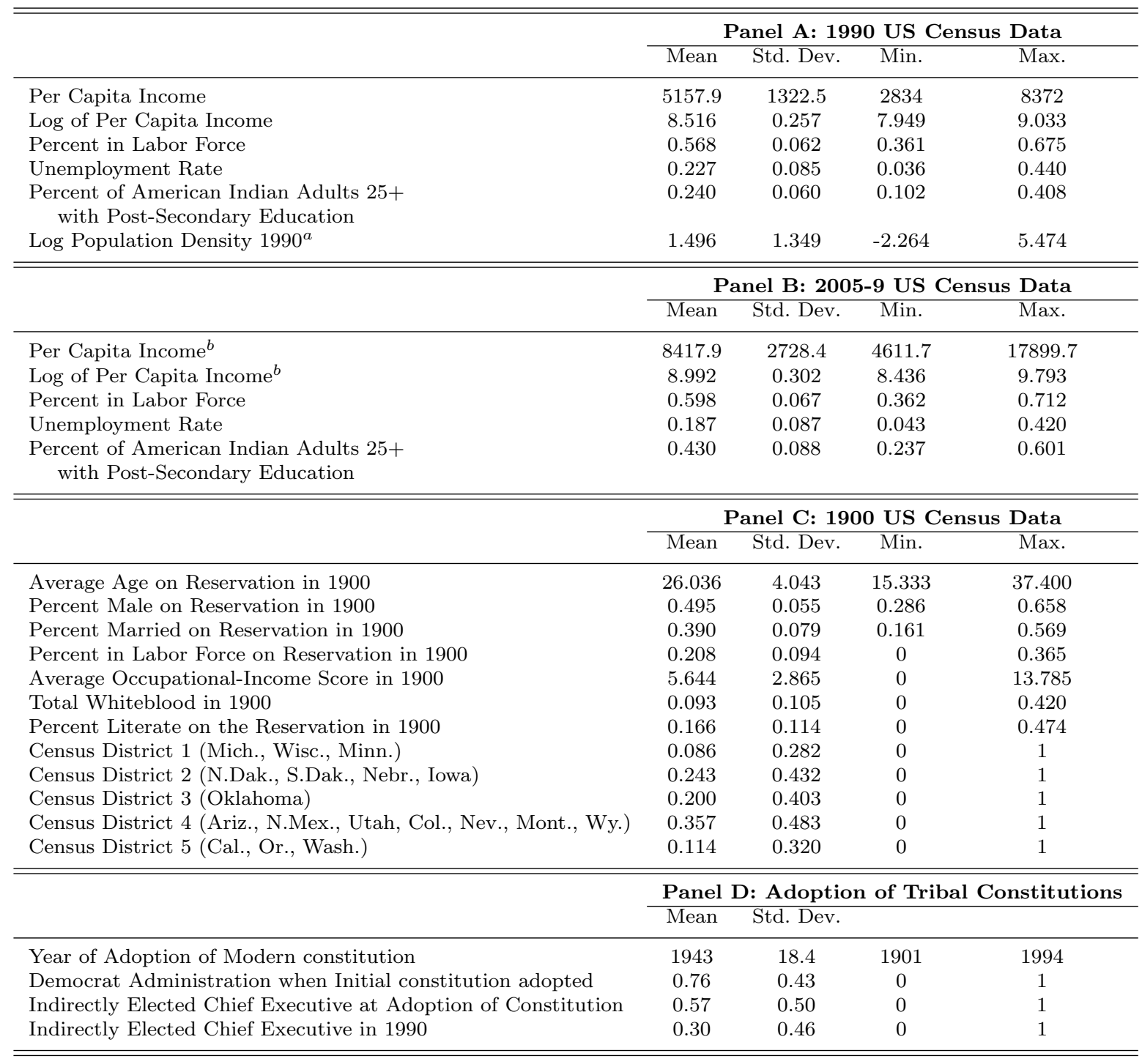

${ }^{a}$ Computed as log of number of inhabitants on Indian lands in 1990 divided by the size of Indian lands in square miles. ${ }^{b}$ Income per capita deflated to prices in 1990.

Table 2: Comparison of Tribal Nations Characteristics Adopted under Republican and Democratic Administrations

\begin{tabular}{|c|c|c|c|c|c|c|c|}
\hline & \multicolumn{6}{|c|}{ Constitution Adopted Under } & \multirow{3}{*}{$\begin{array}{c}\text { Mean Difference } \\
\text { (t-test) }\end{array}$} \\
\hline & \multicolumn{3}{|c|}{ Democrat Presidential Admin. } & \multicolumn{3}{|c|}{ Republican Presidential Admin. } & \\
\hline & Obs. & Mean & Std. Dev. & Obs. & Mean & Std. Dev. & \\
\hline Av. Age on Reservation in 1900 & 53 & 26.147 & 4.230 & 17 & 25.689 & 3.490 & 0.403 \\
\hline \% Male on Reservation in 1900 & 53 & 0.490 & 0.058 & 17 & 0.510 & 0.043 & -1.274 \\
\hline \% Married on Reservation in 1900 & 53 & 0.389 & 0.086 & 17 & 0.393 & 0.056 & -0.172 \\
\hline \% in Labor Force on Reservation in 1900 & 53 & 0.208 & 0.098 & 17 & 0.208 & 0.084 & 0.001 \\
\hline Av. Occ.-Inc. Score in 1900 & 53 & 5.551 & 2.938 & 17 & 5.931 & 2.691 & -0.473 \\
\hline Total Whiteblood in 1900 & 53 & 0.080 & 0.095 & 17 & 0.133 & 0.125 & -1.867 \\
\hline \% Literate on Reservation in 1900 & 53 & 0.155 & 0.107 & 17 & 0.200 & 0.134 & -1.450 \\
\hline Log Population Density 1990 & 53 & 1.523 & 1.239 & 17 & 1.414 & 1.687 & 0.288 \\
\hline
\end{tabular}




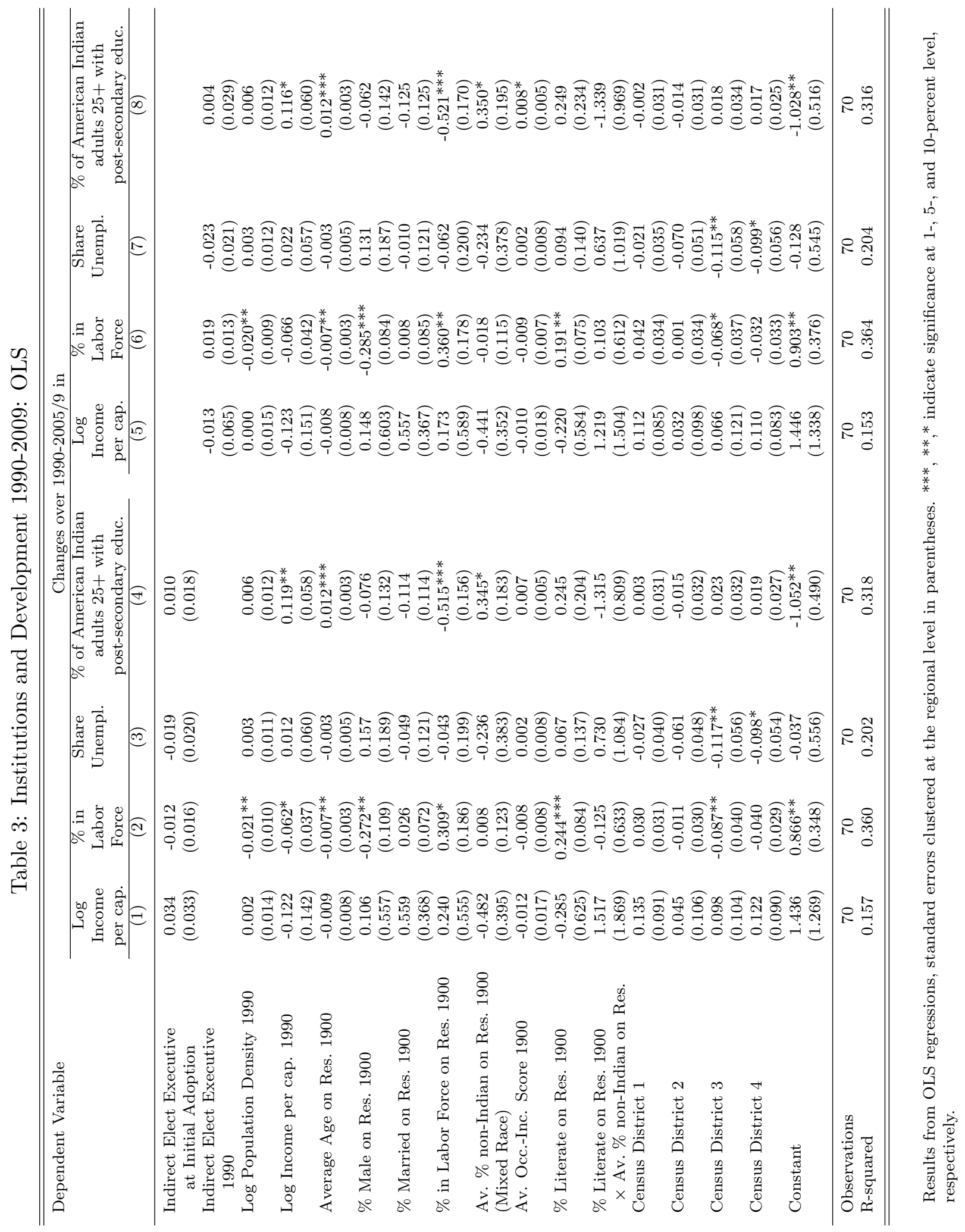


Table 4: Institutions and Development 1990-2009: Reduced Form Estimates

\begin{tabular}{|c|c|c|c|c|}
\hline \multirow[t]{5}{*}{ Dependent Variable } & \multicolumn{4}{|c|}{ Changes over $1990-2005 / 9$ in } \\
\hline & \multirow{4}{*}{$\begin{array}{c}\text { Log } \\
\text { Income } \\
\text { per cap. } \\
(1)\end{array}$} & \multirow{4}{*}{$\begin{array}{l}\% \text { in } \\
\text { Labor } \\
\text { Force } \\
(2)\end{array}$} & \multirow{4}{*}{$\begin{array}{c}\text { Share } \\
\text { Unempl. } \\
(3)\end{array}$} & \multirow{4}{*}{$\begin{array}{l}\text { \% of American Indian } \\
\text { adults } 25+\text { with } \\
\text { post-secondary educ. } \\
(4)\end{array}$} \\
\hline & & & & \\
\hline & & & & \\
\hline & & & & \\
\hline \multirow{2}{*}{$\begin{array}{l}\text { Democrat Federal Administration when } \\
\text { Initial Constitution Adopted }\end{array}$} & $0.123^{* * *}$ & $0.027^{* *}$ & $-0.036^{*}$ & $0.043^{* * *}$ \\
\hline & $(0.035)$ & $(0.011)$ & $(0.019)$ & $(0.016)$ \\
\hline \multirow[t]{2}{*}{ Log Population Density 1990} & 0.001 & $-0.021 * * *$ & 0.004 & 0.006 \\
\hline & $(0.012)$ & $(0.008)$ & $(0.011)$ & $(0.010)$ \\
\hline \multirow[t]{2}{*}{ Log Income per cap. 1990} & -0.200 & $-0.076^{*}$ & 0.036 & 0.092 \\
\hline & $(0.152)$ & $(0.043)$ & $(0.058)$ & $(0.063)$ \\
\hline \multirow{2}{*}{ Average Age on Res. 1900} & -0.005 & $-0.006^{*}$ & -0.004 & $0.013^{* * *}$ \\
\hline & $(0.008)$ & $(0.003)$ & $(0.004)$ & $(0.003)$ \\
\hline \multirow{2}{*}{ \% Male on Res. 1900} & 0.286 & $-0.257 * * *$ & 0.092 & -0.015 \\
\hline & $(0.535)$ & $(0.092)$ & $(0.175)$ & $(0.142)$ \\
\hline \multirow[t]{2}{*}{ \% Married on Res. 1900} & 0.533 & 0.031 & -0.037 & -0.122 \\
\hline & $(0.357)$ & $(0.097)$ & $(0.107)$ & $(0.092)$ \\
\hline \multirow[t]{2}{*}{ \% in Labor Force on Res. 1900} & 0.080 & 0.299 & 0.016 & $-0.569 * * *$ \\
\hline & $(0.571)$ & $(0.185)$ & $(0.171)$ & $(0.164)$ \\
\hline \multirow{2}{*}{$\begin{array}{l}\text { Av. \% non-Indian on Res. } 1900 \\
\text { (Mixed Race) }\end{array}$} & -0.274 & 0.036 & -0.306 & $0.416^{* *}$ \\
\hline & $(0.410)$ & $(0.103)$ & $(0.369)$ & $(0.162)$ \\
\hline \multirow[t]{2}{*}{ Av. Occ.-Inc. Score 1900} & -0.005 & -0.007 & -0.001 & $0.009^{* *}$ \\
\hline & $(0.018)$ & $(0.007)$ & $(0.006)$ & $(0.004)$ \\
\hline \multirow[t]{2}{*}{ \% Literate on Res. 1900} & -0.221 & $0.236^{* * *}$ & 0.038 & 0.266 \\
\hline & $(0.577)$ & $(0.076)$ & $(0.117)$ & $(0.190)$ \\
\hline \multirow{2}{*}{$\begin{array}{l}\text { \% Literate on Res. } 1900 \\
\times \text { Av. \% non-Indian on Res. }\end{array}$} & 1.184 & -0.093 & 0.879 & $-1.423^{*}$ \\
\hline & $(1.715)$ & $(0.531)$ & $(1.092)$ & $(0.774)$ \\
\hline \multirow[t]{2}{*}{ Census District 1} & 0.133 & 0.041 & -0.021 & 0.003 \\
\hline & $(0.085)$ & $(0.035)$ & $(0.030)$ & $(0.032)$ \\
\hline \multirow[t]{2}{*}{ Census District 2} & 0.045 & -0.008 & -0.059 & -0.014 \\
\hline & $(0.111)$ & $(0.032)$ & $(0.045)$ & $(0.032)$ \\
\hline \multirow[t]{2}{*}{ Census District 3} & 0.132 & $-0.065^{* *}$ & $-0.120^{* *}$ & 0.036 \\
\hline & $(0.095)$ & $(0.033)$ & $(0.049)$ & $(0.029)$ \\
\hline \multirow[t]{2}{*}{ Census District 4} & 0.138 & -0.032 & $-0.100^{* *}$ & 0.025 \\
\hline & $(0.093)$ & $(0.030)$ & $(0.051)$ & $(0.028)$ \\
\hline \multirow[t]{2}{*}{ Constant } & 1.815 & $0.922^{* *}$ & -0.162 & $-0.922^{*}$ \\
\hline & $(1.369)$ & $(0.392)$ & $(0.542)$ & $(0.528)$ \\
\hline Observations & 70 & 70 & 70 & 70 \\
\hline R-squared & 0.202 & 0.373 & 0.222 & 0.344 \\
\hline
\end{tabular}

Results from OLS regressions, standard errors clustered at the regional level in parentheses. ***, **,* indicate significance at 1-, 5-, and 10-percent level, respectively. 


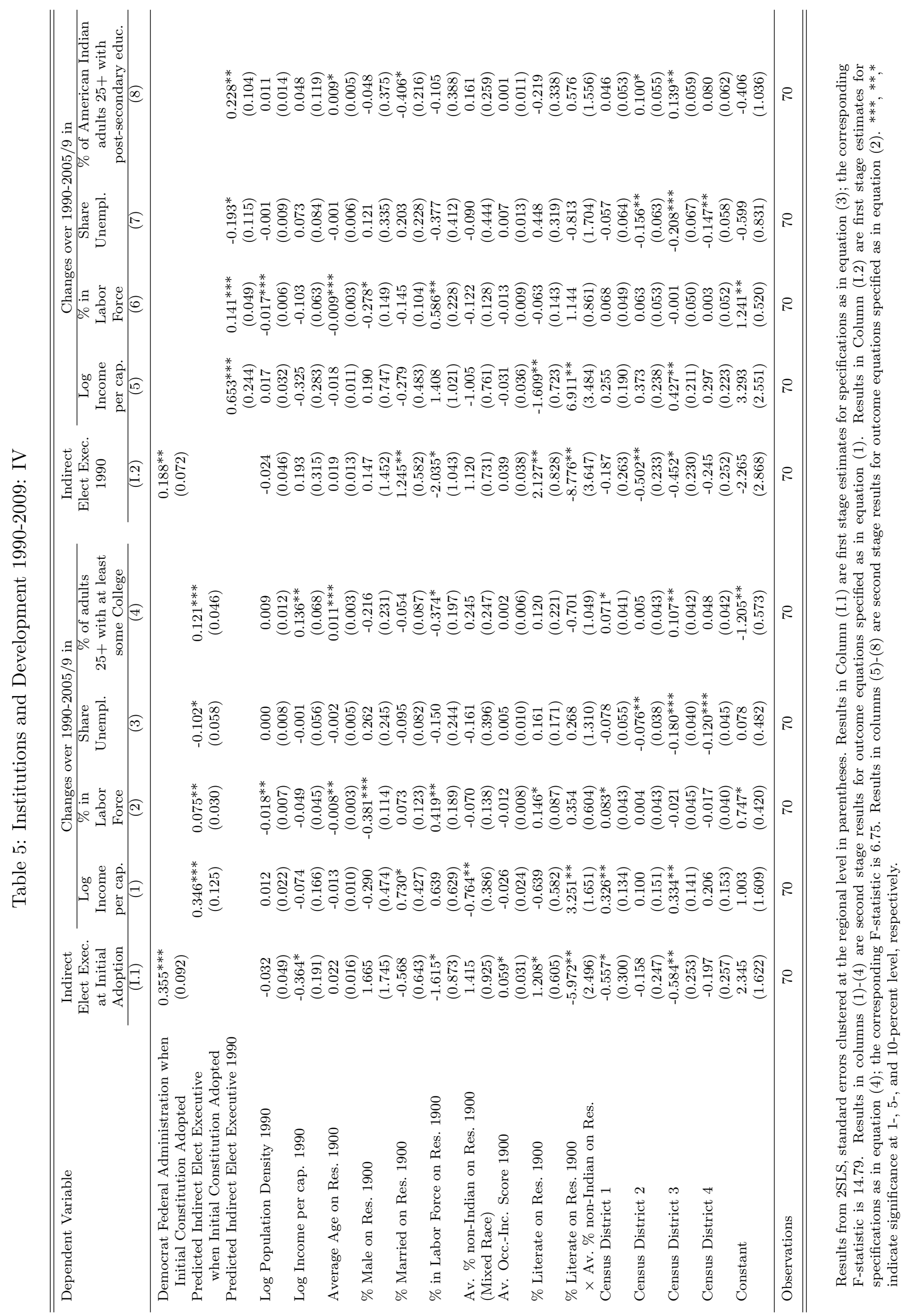


Appendix: Additional Tables 
Table 6: Initial Institutions and Development 1990-2009: Robustness

\begin{tabular}{|c|c|c|c|c|c|}
\hline \multirow[t]{2}{*}{ Dependent Variable } & \multirow{2}{*}{$\begin{array}{c}\text { Indirect } \\
\text { Elect Exec. } \\
\text { at Initial } \\
\text { Adoption }\end{array}$} & \multicolumn{4}{|c|}{ Changes over 1990-2005/9 in } \\
\hline & & $\begin{array}{l}\text { Log } \\
\text { Income } \\
\text { per cap. }\end{array}$ & $\begin{array}{l}\% \text { in } \\
\text { Labor } \\
\text { Force }\end{array}$ & Unemployment & $\begin{array}{l}\% \text { of American Indian } \\
\text { adults } 25+\text { with } \\
\text { post-secondary educ. }\end{array}$ \\
\hline $\begin{array}{l}\text { Democrat Federal Administration when } \\
\text { Initial Constitution Adopted }\end{array}$ & $\begin{array}{c}0.353^{* * *} \\
(0.112)\end{array}$ & & & & \\
\hline $\begin{array}{l}\text { Predicted Indirect Elect Executive } \\
\text { when Initial Constitution Adopted }\end{array}$ & & $\begin{array}{c}0.308^{* * *} \\
(0.107)\end{array}$ & $\begin{array}{c}0.057^{* *} \\
(0.029)\end{array}$ & $\begin{array}{c}-0.102^{*} \\
(0.057)\end{array}$ & $\begin{array}{c}0.124^{* *} \\
(0.053)\end{array}$ \\
\hline Years Since Constitution Initially Adopted & $\begin{array}{c}0.009^{* * *} \\
(0.003)\end{array}$ & $\begin{array}{l}-0.002 \\
(0.002)\end{array}$ & $\begin{array}{c}0.000 \\
(0.000)\end{array}$ & $\begin{array}{c}0.000 \\
(0.001)\end{array}$ & $\begin{array}{l}-0.001 \\
(0.001)\end{array}$ \\
\hline Distance to Nearest City (miles) & $\begin{array}{c}0.057 \\
(0.081)\end{array}$ & $\begin{array}{l}-0.084 \\
(0.061)\end{array}$ & $\begin{array}{c}-0.030 * * * \\
(0.009)\end{array}$ & $\begin{array}{c}0.001 \\
(0.009)\end{array}$ & $\begin{array}{c}0.001 \\
(0.016)\end{array}$ \\
\hline Log Population Density 1990 & $\begin{array}{l}-0.025 \\
(0.041)\end{array}$ & $\begin{array}{l}0.001 \\
(0.017)\end{array}$ & $\begin{array}{c}-0.023 * * * \\
(0.007)\end{array}$ & $\begin{array}{c}0.000 \\
(0.009)\end{array}$ & $\begin{array}{c}0.010 \\
(0.012)\end{array}$ \\
\hline Log Income per cap. 1990 & $\begin{array}{l}-0.353^{*} \\
(0.180)\end{array}$ & $\begin{array}{l}-0.118 \\
(0.154)\end{array}$ & $\begin{array}{l}-0.067 \\
(0.048)\end{array}$ & $\begin{array}{l}-0.001 \\
(0.059)\end{array}$ & $\begin{array}{c}0.138^{* *} \\
(0.065)\end{array}$ \\
\hline Average Age on Res. 1900 & $\begin{array}{c}0.028 \\
(0.017)\end{array}$ & $\begin{array}{l}-0.013 \\
(0.009)\end{array}$ & $\begin{array}{c}-0.007^{* *} \\
(0.003)\end{array}$ & $\begin{array}{l}-0.002 \\
(0.005)\end{array}$ & $\begin{array}{c}0.010^{* * *} \\
(0.003)\end{array}$ \\
\hline \% Male on Res. 1900 & $\begin{array}{l}1.695 \\
(1.684)\end{array}$ & $\begin{array}{l}-0.075 \\
(0.494)\end{array}$ & $\begin{array}{c}-0.284^{* * *} \\
(0.107)\end{array}$ & $\begin{array}{l}0.264 \\
(0.248)\end{array}$ & $\begin{array}{l}-0.235 \\
(0.232)\end{array}$ \\
\hline \% Married on Res. 1900 & $\begin{array}{l}-0.472 \\
(0.605)\end{array}$ & $\begin{array}{l}0.752^{*} \\
(0.412)\end{array}$ & $\begin{array}{c}0.092 \\
(0.114)\end{array}$ & $\begin{array}{l}-0.093 \\
(0.083)\end{array}$ & $\begin{array}{l}-0.063 \\
(0.098)\end{array}$ \\
\hline \% in Labor Force on Res. 1900 & $\begin{array}{l}-1.495 \\
(1.211)\end{array}$ & $\begin{array}{l}-0.007 \\
(0.898)\end{array}$ & $\begin{array}{c}0.152 \\
(0.111)\end{array}$ & $\begin{array}{l}-0.149 \\
(0.206)\end{array}$ & $\begin{array}{l}-0.338 \\
(0.230)\end{array}$ \\
\hline $\begin{array}{l}\text { Av. \% non-Indian on Res. } 1900 \\
\text { (Mixed Race) }\end{array}$ & $\begin{array}{c}0.888 \\
(1.158)\end{array}$ & $\begin{array}{l}-0.399 \\
(0.458)\end{array}$ & $\begin{array}{c}0.033 \\
(0.112)\end{array}$ & $\begin{array}{l}-0.168 \\
(0.366)\end{array}$ & $\begin{array}{c}0.263 \\
(0.278)\end{array}$ \\
\hline Av. Occ.-Inc. Score 1900 & $\begin{array}{l}0.063 \\
(0.041)\end{array}$ & $\begin{array}{l}-0.013 \\
(0.025)\end{array}$ & $\begin{array}{l}-0.006 \\
(0.005)\end{array}$ & $\begin{array}{l}0.005 \\
(0.009)\end{array}$ & $\begin{array}{l}0.001 \\
(0.007)\end{array}$ \\
\hline \% Literate on Res. 1900 & $\begin{array}{c}1.257^{* *} \\
(0.574)\end{array}$ & $\begin{array}{l}-0.623 \\
(0.559)\end{array}$ & $\begin{array}{l}0.159^{*} \\
(0.085)\end{array}$ & $\begin{array}{c}0.162 \\
(0.177)\end{array}$ & $\begin{array}{l}0.114 \\
(0.246)\end{array}$ \\
\hline $\begin{array}{l}\text { \% Literate on Res. } 1900 \\
\times \text { Av. \% non-Indian on Res. }\end{array}$ & $\begin{array}{l}-2.972 \\
(3.003)\end{array}$ & $\begin{array}{l}2.049 \\
(1.888)\end{array}$ & $\begin{array}{l}0.152 \\
(0.491)\end{array}$ & $\begin{array}{c}0.313 \\
(1.223)\end{array}$ & $\begin{array}{l}-0.870 \\
(1.054)\end{array}$ \\
\hline Census District 1 & $\begin{array}{c}-0.478^{* *} \\
(0.224)\end{array}$ & $\begin{array}{c}0.255^{* * *} \\
(0.096)\end{array}$ & $\begin{array}{c}0.060 \\
(0.038)\end{array}$ & $\begin{array}{l}-0.077 \\
(0.050)\end{array}$ & $\begin{array}{c}0.069 \\
(0.043)\end{array}$ \\
\hline Census District 2 & $\begin{array}{l}-0.186 \\
(0.202)\end{array}$ & $\begin{array}{c}0.097 \\
(0.123)\end{array}$ & $\begin{array}{l}-0.000 \\
(0.034)\end{array}$ & $\begin{array}{l}-0.076^{*} \\
(0.040)\end{array}$ & $\begin{array}{l}0.008 \\
(0.042)\end{array}$ \\
\hline Census District 3 & $\begin{array}{l}-0.402^{*} \\
(0.225)\end{array}$ & $\begin{array}{l}0.191^{*} \\
(0.111)\end{array}$ & $\begin{array}{l}-0.064^{*} \\
(0.038)\end{array}$ & $\begin{array}{c}-0.178^{* * *} \\
(0.039)\end{array}$ & $\begin{array}{c}0.102^{* *} \\
(0.042)\end{array}$ \\
\hline Census District 4 & $\begin{array}{l}-0.194 \\
(0.217)\end{array}$ & $\begin{array}{l}0.188 \\
(0.124)\end{array}$ & $\begin{array}{l}-0.025 \\
(0.032)\end{array}$ & $\begin{array}{c}-0.120^{* * * *} \\
(0.046)\end{array}$ & $\begin{array}{l}0.049 \\
(0.040)\end{array}$ \\
\hline Constant & $\begin{array}{l}1.449 \\
(1.543)\end{array}$ & $\begin{array}{c}1.611 \\
(1.556)\end{array}$ & $\begin{array}{c}0.915^{* *} \\
(0.456)\end{array}$ & $\begin{array}{l}0.065 \\
(0.497)\end{array}$ & $\begin{array}{c}-1.173^{* *} \\
(0.567)\end{array}$ \\
\hline Observations & 70 & 70 & 70 & 70 & 70 \\
\hline
\end{tabular}

Results from 2SLS, standard errors clustered at the regional level in parentheses. Results in Column (1) are first stage estimates. Results in other columns are second stage estimates. $* * *, * * *$ indicate significance at 1-, 5-, and 10-percent level, respectively. 
Table 7: Institutions and Development 1990-2009: IV (specific controls)

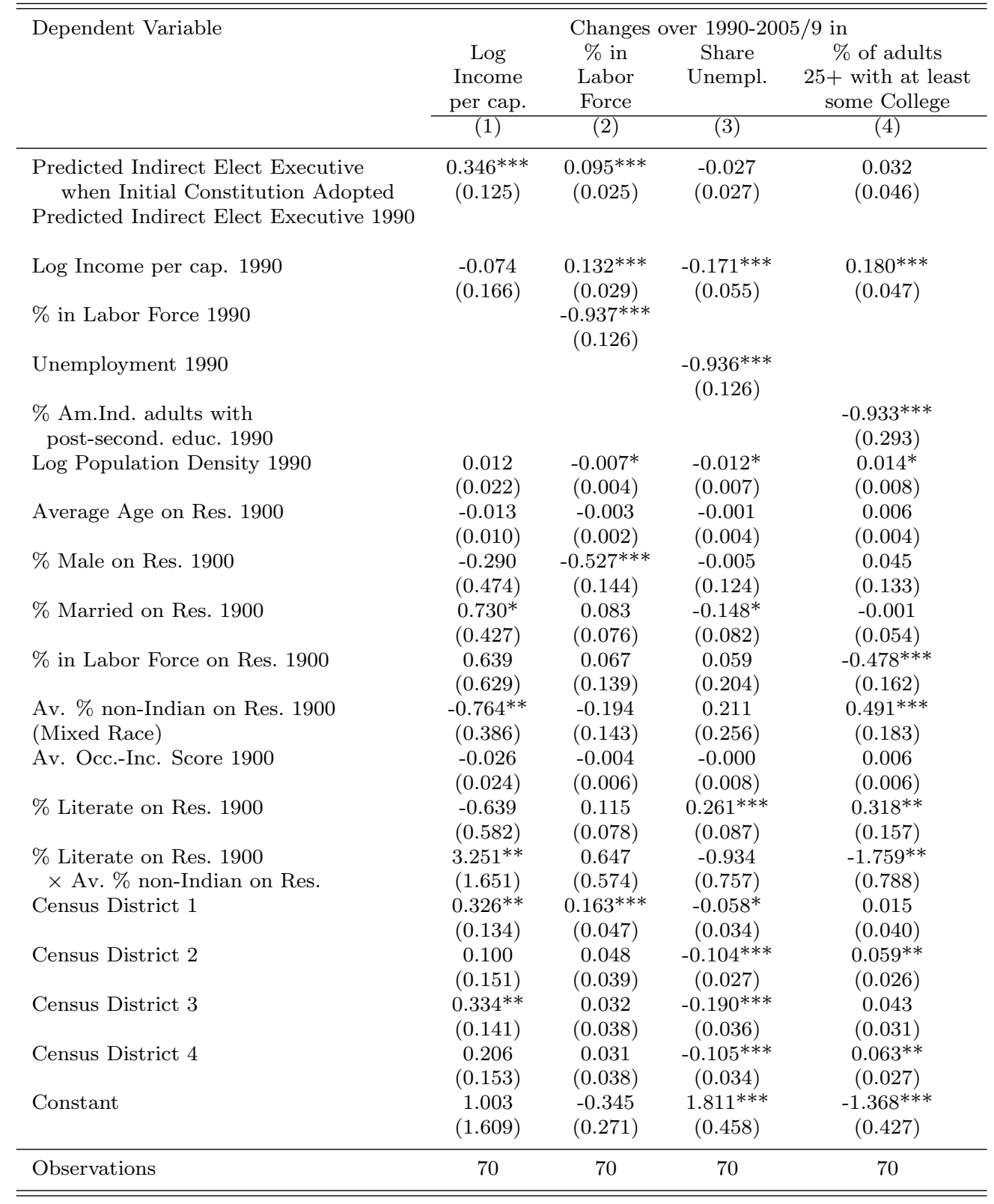

Second stage results from 2SLS, standard errors clustered at the regional level in parentheses. First stage uses Democrat Federal Administration when constitution initially adopted as instrument. ***, **,* indicate significance at 1-, 5-, and 10-percent level, respectively. 
Table 8: Initial Institutions and Development 1990-2009: IV (extended specification)

\begin{tabular}{|c|c|c|c|c|c|}
\hline \multirow[t]{2}{*}{ Dependent Variable } & \multirow{2}{*}{$\begin{array}{c}\text { Indirepct } \\
\text { Elect Exec. } \\
\text { at Initial } \\
\text { Adoption }\end{array}$} & \multicolumn{4}{|c|}{ Changes over 1990-2005/9 in } \\
\hline & & $\begin{array}{l}\text { Log } \\
\text { Income } \\
\text { per cap. }\end{array}$ & $\begin{array}{l}\% \text { in } \\
\text { Labor } \\
\text { Force }\end{array}$ & Unemployment & $\begin{array}{l}\% \text { of American Indian } \\
\text { adults } 25+\text { with } \\
\text { post-secondary educ. }\end{array}$ \\
\hline $\begin{array}{l}\text { Democrat Federal Administration when } \\
\text { Initial Constitution Adopted }\end{array}$ & $\begin{array}{c}0.397^{* * *} \\
(0.101)\end{array}$ & & & & \\
\hline $\begin{array}{l}\text { Predicted Indirect Elect Executive } \\
\text { when Initial Constitution Adopted }\end{array}$ & & $\begin{array}{c}0.212^{* *} \\
(0.102)\end{array}$ & $\begin{array}{c}0.089^{* *} \\
(0.035)\end{array}$ & $\begin{array}{l}-0.043 \\
(0.034)\end{array}$ & $\begin{array}{l}-0.010 \\
(0.040)\end{array}$ \\
\hline Log Income per cap. 1990 & $\begin{array}{c}-0.787^{* *} \\
(0.282)\end{array}$ & $\begin{array}{c}0.430^{* *} \\
(0.183)\end{array}$ & $\begin{array}{c}0.142^{* * *} \\
(0.027)\end{array}$ & $\begin{array}{c}-0.159^{* *} \\
(0.077)\end{array}$ & $\begin{array}{c}0.299^{* * *} \\
(0.056)\end{array}$ \\
\hline \% in Labor Force 1990 & $\begin{array}{c}0.806 \\
(0.950)\end{array}$ & $\begin{array}{c}-1.776^{* * * *} \\
(0.454)\end{array}$ & $\begin{array}{c}-0.923^{* * *} \\
(0.140)\end{array}$ & $\begin{array}{l}-0.021 \\
(0.168)\end{array}$ & $\begin{array}{l}-0.194 \\
(0.153)\end{array}$ \\
\hline Unemployment 1990 & $\begin{array}{l}-1.123 \\
(0.988)\end{array}$ & $\begin{array}{c}0.535 \\
(0.345)\end{array}$ & $\begin{array}{c}0.071 \\
(0.130)\end{array}$ & $\begin{array}{c}-0.934^{* * *} \\
(0.114)\end{array}$ & $\begin{array}{c}0.412^{* * *} \\
(0.117)\end{array}$ \\
\hline $\begin{array}{l}\% \text { Am.Ind. adults with } \\
\text { post-second. educ. } 1990\end{array}$ & $\begin{array}{l}0.460 \\
(0.971)\end{array}$ & $\begin{array}{c}-1.360^{* * *} \\
(0.418)\end{array}$ & $\begin{array}{c}0.006 \\
(0.274)\end{array}$ & $\begin{array}{l}-0.169 \\
(0.109)\end{array}$ & $\begin{array}{c}-1.069^{* * *} \\
(0.246)\end{array}$ \\
\hline Log Population Density 1990 & $\begin{array}{l}-0.063 \\
(0.052)\end{array}$ & $\begin{array}{l}0.047^{*} \\
(0.027)\end{array}$ & $\begin{array}{l}-0.006 \\
(0.005)\end{array}$ & $\begin{array}{c}-0.011^{*} \\
(0.006)\end{array}$ & $\begin{array}{c}0.022^{* * *} \\
(0.005)\end{array}$ \\
\hline Average Age on Res. 1900 & $\begin{array}{l}0.024 \\
(0.020)\end{array}$ & $\begin{array}{l}-0.012 \\
(0.009)\end{array}$ & $\begin{array}{l}-0.003 \\
(0.003)\end{array}$ & $\begin{array}{l}-0.002 \\
(0.003)\end{array}$ & $\begin{array}{l}0.005 \\
(0.003)\end{array}$ \\
\hline \% Male on Res. 1900 & $\begin{array}{l}1.536 \\
(1.625)\end{array}$ & $\begin{array}{l}-0.034 \\
(0.364)\end{array}$ & $\begin{array}{c}-0.506^{* * *} \\
(0.165)\end{array}$ & $\begin{array}{c}0.040 \\
(0.140)\end{array}$ & $\begin{array}{l}0.171^{*} \\
(0.098)\end{array}$ \\
\hline \% Married on Res. 1900 & $\begin{array}{l}-0.733 \\
(0.657)\end{array}$ & $\begin{array}{c}0.856^{* *} \\
(0.335)\end{array}$ & $\begin{array}{c}0.086 \\
(0.068)\end{array}$ & $\begin{array}{l}-0.138^{*} \\
(0.077)\end{array}$ & $\begin{array}{c}0.033 \\
(0.063)\end{array}$ \\
\hline \% in Labor Force on Res. 1900 & $\begin{array}{l}-1.199 \\
(0.883)\end{array}$ & $\begin{array}{l}-0.301 \\
(0.587)\end{array}$ & $\begin{array}{l}0.057 \\
(0.129)\end{array}$ & $\begin{array}{l}0.031 \\
(0.167)\end{array}$ & $\begin{array}{c}-0.658^{* * *} \\
(0.124)\end{array}$ \\
\hline $\begin{array}{l}\text { Av. \% non-Indian on Res. } 1900 \\
\text { (Mixed Race) }\end{array}$ & $\begin{array}{l}2.012^{*} \\
(1.023)\end{array}$ & $\begin{array}{c}-0.853^{* *} \\
(0.332)\end{array}$ & $\begin{array}{c}-0.222^{* *} \\
(0.106)\end{array}$ & $\begin{array}{c}0.252 \\
(0.235)\end{array}$ & $\begin{array}{l}0.337^{*} \\
(0.179)\end{array}$ \\
\hline Av. Occ.-Inc. Score 1900 & $\begin{array}{c}0.050 \\
(0.035)\end{array}$ & $\begin{array}{l}-0.002 \\
(0.021)\end{array}$ & $\begin{array}{l}-0.003 \\
(0.005)\end{array}$ & $\begin{array}{c}0.000 \\
(0.008)\end{array}$ & $\begin{array}{c}0.011^{* *} \\
(0.005)\end{array}$ \\
\hline \% Literate on Res. 1900 & $\begin{array}{l}1.398^{* *} \\
(0.641)\end{array}$ & $\begin{array}{l}-0.465 \\
(0.481)\end{array}$ & $\begin{array}{c}0.107 \\
(0.101)\end{array}$ & $\begin{array}{c}0.296^{* * *} \\
(0.087)\end{array}$ & $\begin{array}{c}0.297^{* * *} \\
(0.102)\end{array}$ \\
\hline $\begin{array}{l}\text { \% Literate on Res. } 1900 \\
\times \text { Av. \% non-Indian on Res. }\end{array}$ & $\begin{array}{c}-7.844^{* *} \\
(2.991)\end{array}$ & $\begin{array}{l}2.953^{* *} \\
(1.487)\end{array}$ & $\begin{array}{l}0.741 \\
(0.595)\end{array}$ & $\begin{array}{l}-1.117 \\
(0.688)\end{array}$ & $\begin{array}{c}-1.323^{* *} \\
(0.621)\end{array}$ \\
\hline Census District 1 & $\begin{array}{l}-0.639^{*} \\
(0.320)\end{array}$ & $\begin{array}{c}0.384^{* * *} \\
(0.139)\end{array}$ & $\begin{array}{c}0.160^{* * *} \\
(0.051)\end{array}$ & $\begin{array}{l}-0.066 \\
(0.046)\end{array}$ & $\begin{array}{c}0.015 \\
(0.032)\end{array}$ \\
\hline Census District 2 & $\begin{array}{l}-0.275 \\
(0.211)\end{array}$ & $\begin{array}{l}0.279^{*} \\
(0.150)\end{array}$ & $\begin{array}{c}0.049 \\
(0.032)\end{array}$ & $\begin{array}{c}-0.094^{* * *} \\
(0.025)\end{array}$ & $\begin{array}{c}0.089^{* * *} * \\
(0.026)\end{array}$ \\
\hline Census District 3 & $\begin{array}{c}-0.679^{* *} \\
(0.277)\end{array}$ & $\begin{array}{c}0.348^{* *} \\
(0.136)\end{array}$ & $\begin{array}{c}0.033 \\
(0.047)\end{array}$ & $\begin{array}{c}-0.200^{* * *} \\
(0.040)\end{array}$ & $\begin{array}{l}0.049^{*} \\
(0.026)\end{array}$ \\
\hline Census District 4 & $\begin{array}{l}-0.250 \\
(0.230)\end{array}$ & $\begin{array}{c}0.309 * * \\
(0.139)\end{array}$ & $\begin{array}{c}0.029 \\
(0.034)\end{array}$ & $\begin{array}{c}-0.102^{* * *} \\
(0.033)\end{array}$ & $\begin{array}{c}0.068^{* * *} \\
(0.024)\end{array}$ \\
\hline Constant & $\begin{array}{c}5.718^{* *} \\
(2.611)\end{array}$ & $\begin{array}{l}-2.295 \\
(1.593)\end{array}$ & $\begin{array}{l}-0.460 \\
(0.343)\end{array}$ & $\begin{array}{c}1.754^{* * *} * \\
(0.555)\end{array}$ & $\begin{array}{c}-2.381^{* * *} \\
(0.546)\end{array}$ \\
\hline Observations & 70 & 70 & 70 & 70 & 70 \\
\hline
\end{tabular}

Second stage results from 2SLS, standard errors clustered at the regional level in parentheses. First stage uses Democrat Federal Administration when constitution initially adopted as instrument. ***, **,* indicate significance at 1-, 5-, and 10-percent level, respectively. 
Table 9: Initial Institutions and Development 1990-2009: IV Results Controlling for Other Constitutional Details

\begin{tabular}{|c|c|c|c|c|c|c|c|}
\hline \multirow{3}{*}{$\begin{array}{l}\text { Dependent Variable } \\
\text { Predicted Indirect Elect Executive } \\
\text { when Initial Constitution Adopted } \\
\text { Judiciary Exists? }\end{array}$} & \multicolumn{7}{|c|}{ Change in log Income per capita 1990-2005/9 } \\
\hline & $\begin{array}{c}0.430 * * \\
(0.198)\end{array}$ & $\begin{array}{l}0.408^{*} \\
(0.212)\end{array}$ & $\begin{array}{c}0.403^{* *} \\
(0.193)\end{array}$ & $\begin{array}{c}0.350^{* *} \\
(0.141)\end{array}$ & $\begin{array}{c}0.383^{* *} \\
(0.189)\end{array}$ & $\begin{array}{c}0.321^{* *} \\
(0.125)\end{array}$ & $\begin{array}{l}0.603^{*} \\
(0.314)\end{array}$ \\
\hline & $\begin{array}{c}0.164 \\
(0.116)\end{array}$ & & & & & & $\begin{array}{c}0.271 \\
(0.167)\end{array}$ \\
\hline Staggered Election Terms? & & $\begin{array}{l}-0.040 \\
(0.067)\end{array}$ & & & & & $\begin{array}{l}-0.110 \\
(0.077)\end{array}$ \\
\hline Term Length & & & $\begin{array}{l}-0.001 \\
(0.001)\end{array}$ & & & & $\begin{array}{l}-0.003 \\
(0.003)\end{array}$ \\
\hline Council Directly Elected? & & & & $\begin{array}{c}0.238^{* *} \\
(0.106)\end{array}$ & & & $\begin{array}{l}0.330^{*} \\
(0.179)\end{array}$ \\
\hline Tribal Council Size & & & & & $\begin{array}{l}-0.001 \\
(0.001)\end{array}$ & & $\begin{array}{c}0.002 \\
(0.003)\end{array}$ \\
\hline Operates a Casino? & & & & & & $\begin{array}{l}-0.012 \\
(0.052)\end{array}$ & $\begin{array}{c}0.036 \\
(0.095)\end{array}$ \\
\hline Observations & 70 & 68 & 68 & 68 & 68 & 70 & 68 \\
\hline
\end{tabular}

Second stage results from 2SLS regressions, standard errors clustered at the regional level in parentheses. All specifications include the standard control variables as in Table 3 but coefficients are not shown for reasons of space. First stages correspond to appropriately modified specifications of $[3] . * * *, * *, *$ indicate significance at 1-, 5-, and 10-percent level, respectively. 


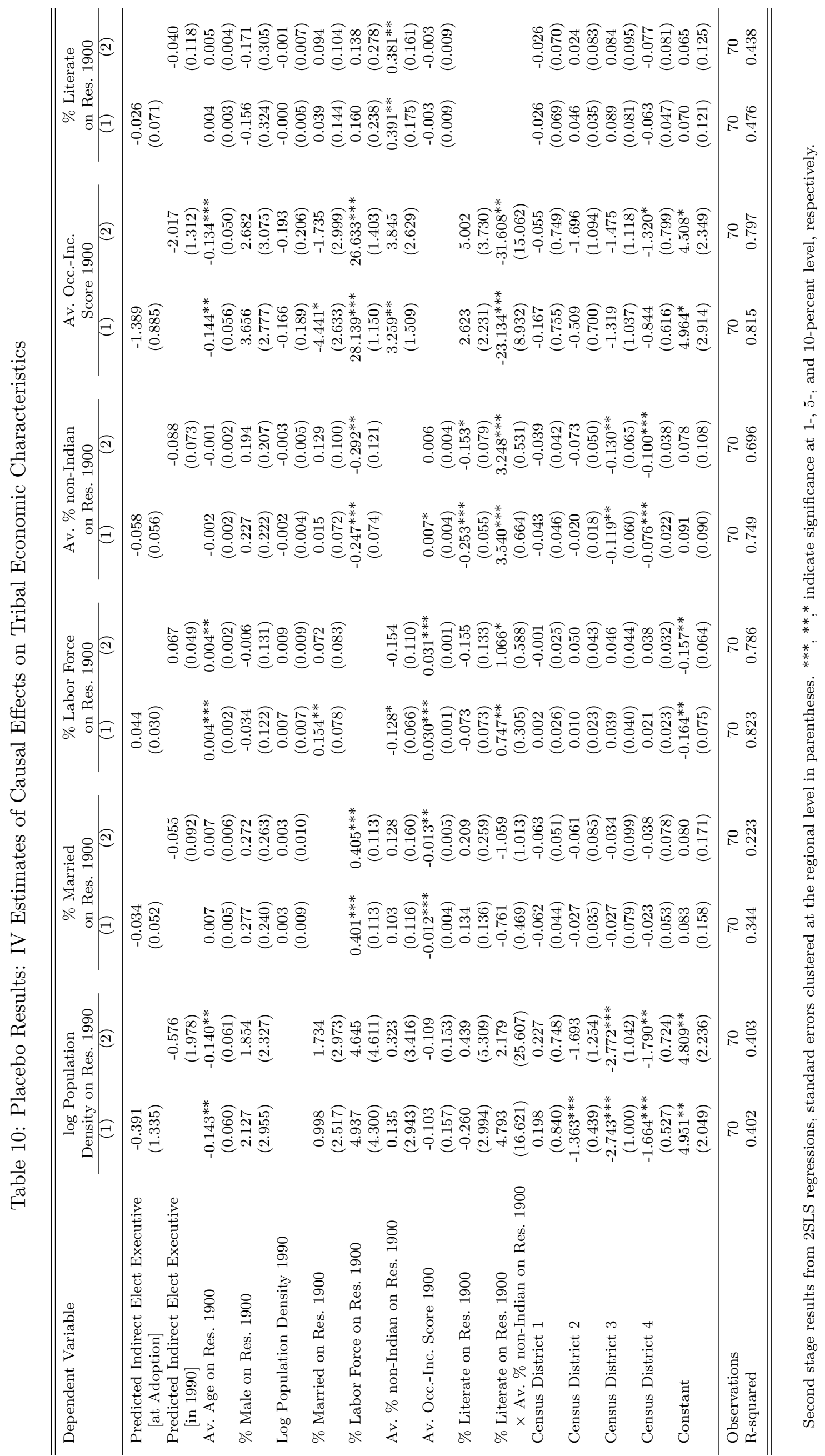


Table 11: Institutions and Development 1990-2009: Public and Private Employment, Income Distribution

\begin{tabular}{|c|c|c|c|}
\hline \multirow[t]{4}{*}{ Dependent Variable } & \multicolumn{3}{|c|}{ Changes over 1990-2005/9 in } \\
\hline & $\begin{array}{l}\text { Government Employment } \\
\text { (as \% of Adult Pop.) }\end{array}$ & $\begin{array}{l}\text { Private Employment } \\
\text { (as \% of Adult Pop.) }\end{array}$ & $\begin{array}{l}\text { Poverty Rate } \\
\text { (\% households below contemporaneous }\end{array}$ \\
\hline & & & US median household income) \\
\hline & (1) & $(2)$ & (3) \\
\hline $\begin{array}{l}\text { Predicted Indirect Elect Executive } \\
\text { [at Adoption] }\end{array}$ & $\begin{array}{l}0.054^{*} \\
(0.031)\end{array}$ & $\begin{array}{l}-0.003 \\
(0.022)\end{array}$ & $\begin{array}{c}-0.125^{* *} \\
(0.054)\end{array}$ \\
\hline $\begin{array}{l}\text { Government Employment } 1990 \\
\text { (as \% of Adult Pop.) }\end{array}$ & $\begin{array}{c}-0.278^{*} \\
(0.162)\end{array}$ & & \\
\hline $\begin{array}{l}\text { Private Employment } 1990 \\
\text { (as \% of Adult Pop.) }\end{array}$ & & $\begin{array}{l}-0.212^{* * *} \\
(0.066)\end{array}$ & \\
\hline $\begin{array}{l}\text { \% of all Households below } \\
\text { Median Household Income } 1990\end{array}$ & & & $\begin{array}{l}-0.440 \\
(0.306)\end{array}$ \\
\hline Log Population Density 1990 & $\begin{array}{l}-0.009 \\
(0.008)\end{array}$ & $\begin{array}{c}-0.009 * \\
(0.005)\end{array}$ & $\begin{array}{c}0.003 \\
(0.011)\end{array}$ \\
\hline Unemployment 1990 & $\begin{array}{c}0.195^{* *} \\
(0.090)\end{array}$ & $\begin{array}{l}0.125 \\
(0.142)\end{array}$ & $\begin{array}{l}-0.039 \\
(0.229)\end{array}$ \\
\hline Log Income per cap. 1990 & $\begin{array}{l}0.000 \\
(0.032)\end{array}$ & $\begin{array}{l}0.057 \\
(0.050)\end{array}$ & $\begin{array}{l}-0.112 \\
(0.079)\end{array}$ \\
\hline Average Age on Res. 1900 & $\begin{array}{l}-0.002 \\
(0.003)\end{array}$ & $\begin{array}{l}-0.000 \\
(0.003)\end{array}$ & $\begin{array}{c}0.003 \\
(0.005)\end{array}$ \\
\hline \% Male on Res. 1900 & $\begin{array}{l}-0.236 \\
(0.167)\end{array}$ & $\begin{array}{c}0.069 \\
(0.147)\end{array}$ & $\begin{array}{l}0.237 \\
(0.177)\end{array}$ \\
\hline \% Married on Res. 1900 & $\begin{array}{c}0.134 \\
(0.120)\end{array}$ & $\begin{array}{c}0.113 \\
(0.106)\end{array}$ & $\begin{array}{l}-0.158 \\
(0.169)\end{array}$ \\
\hline \% in Labor Force on Res. 1900 & $\begin{array}{l}-0.294 \\
(0.228)\end{array}$ & $\begin{array}{l}-0.096 \\
(0.092)\end{array}$ & $\begin{array}{l}-0.210 \\
(0.436)\end{array}$ \\
\hline $\begin{array}{l}\text { Av. \% non-Indian on Res. } 1900 \\
\text { (Mixed Race) }\end{array}$ & $\begin{array}{c}-0.168^{* * *} \\
(0.063)\end{array}$ & $\begin{array}{c}-0.140^{* *} \\
(0.064)\end{array}$ & $\begin{array}{c}0.339 \\
(0.282)\end{array}$ \\
\hline Av. Occ.-Inc. Score 1900 & $\begin{array}{l}0.014 \\
(0.009)\end{array}$ & $\begin{array}{l}0.001 \\
(0.004)\end{array}$ & $\begin{array}{c}0.012 \\
(0.015)\end{array}$ \\
\hline \% Literate on Res. 1900 & $\begin{array}{c}0.004 \\
(0.103)\end{array}$ & $\begin{array}{c}-0.175^{* *} \\
(0.078)\end{array}$ & $\begin{array}{l}0.141 \\
(0.141)\end{array}$ \\
\hline $\begin{array}{l}\text { \% Literate on Res. } 1900 \\
\times \text { Av. \% non-Indian on Res. }\end{array}$ & $\begin{array}{c}0.564 \\
(0.401)\end{array}$ & $\begin{array}{l}0.984^{* *} \\
(0.401)\end{array}$ & $\begin{array}{l}-1.074 \\
(0.993)\end{array}$ \\
\hline Census District 1 & $\begin{array}{c}0.001 \\
(0.036)\end{array}$ & $\begin{array}{l}0.051^{* *} \\
(0.025)\end{array}$ & $\begin{array}{l}-0.104 \\
(0.085)\end{array}$ \\
\hline Census District 2 & $\begin{array}{l}0.005 \\
(0.027)\end{array}$ & $\begin{array}{c}0.037 \\
(0.027)\end{array}$ & $\begin{array}{l}-0.025 \\
(0.051)\end{array}$ \\
\hline Census District 3 & $\begin{array}{l}-0.011 \\
(0.045)\end{array}$ & $\begin{array}{c}0.042 \\
(0.041)\end{array}$ & $\begin{array}{l}-0.107^{*} \\
(0.061)\end{array}$ \\
\hline Census District 4 & $\begin{array}{l}0.034 \\
(0.030)\end{array}$ & $\begin{array}{l}-0.014 \\
(0.027)\end{array}$ & $\begin{array}{l}-0.013 \\
(0.056)\end{array}$ \\
\hline Constant & $\begin{array}{c}0.121 \\
(0.263)\end{array}$ & $\begin{array}{l}-0.504 \\
(0.439)\end{array}$ & $\begin{array}{l}1.052 \\
(0.960)\end{array}$ \\
\hline Observations & 70 & 70 & 70 \\
\hline R-squared & 0.338 & 0.306 & -0.0907 \\
\hline
\end{tabular}

Results from 2SLS regressions, instrumentation as in 3. Standard errors clustered at the regional level in parentheses. ***, **,* indicate significance at $1-, 5-$, and 10 -percent level, respectively. 